\title{
WPS3561
}

\section{Activities, Employment, and Wages in Rural and Semi-Urban Mexico}

\author{
By
}

\author{
Dorte Verner ${ }^{1}$ \\ dverner@worldbank.org
}

World Bank Policy Research Working Paper 3561, April 2005

The Policy Research Working Paper Series disseminates the findings of work in progress to encourage the exchange of ideas about development issues. An objective of the series is to get the findings out quickly, even if the presentations are less than fully polished. The papers carry the names of the authors and should be cited accordingly. The findings, interpretations, and conclusions expressed in this paper are entirely those of the authors. They do not necessarily represent the view of the World Bank, its Executive Directors, or the countries they represent. Policy Research Working Papers are available online at http://econ.worldbank.org.

\footnotetext{
${ }^{1}$ I am very grateful to José María Caballero for inviting me to write this paper and Mario Torres Falcon for excellent and invaluable research assistance.
} 


\section{Map 1. Regions of Mexico}

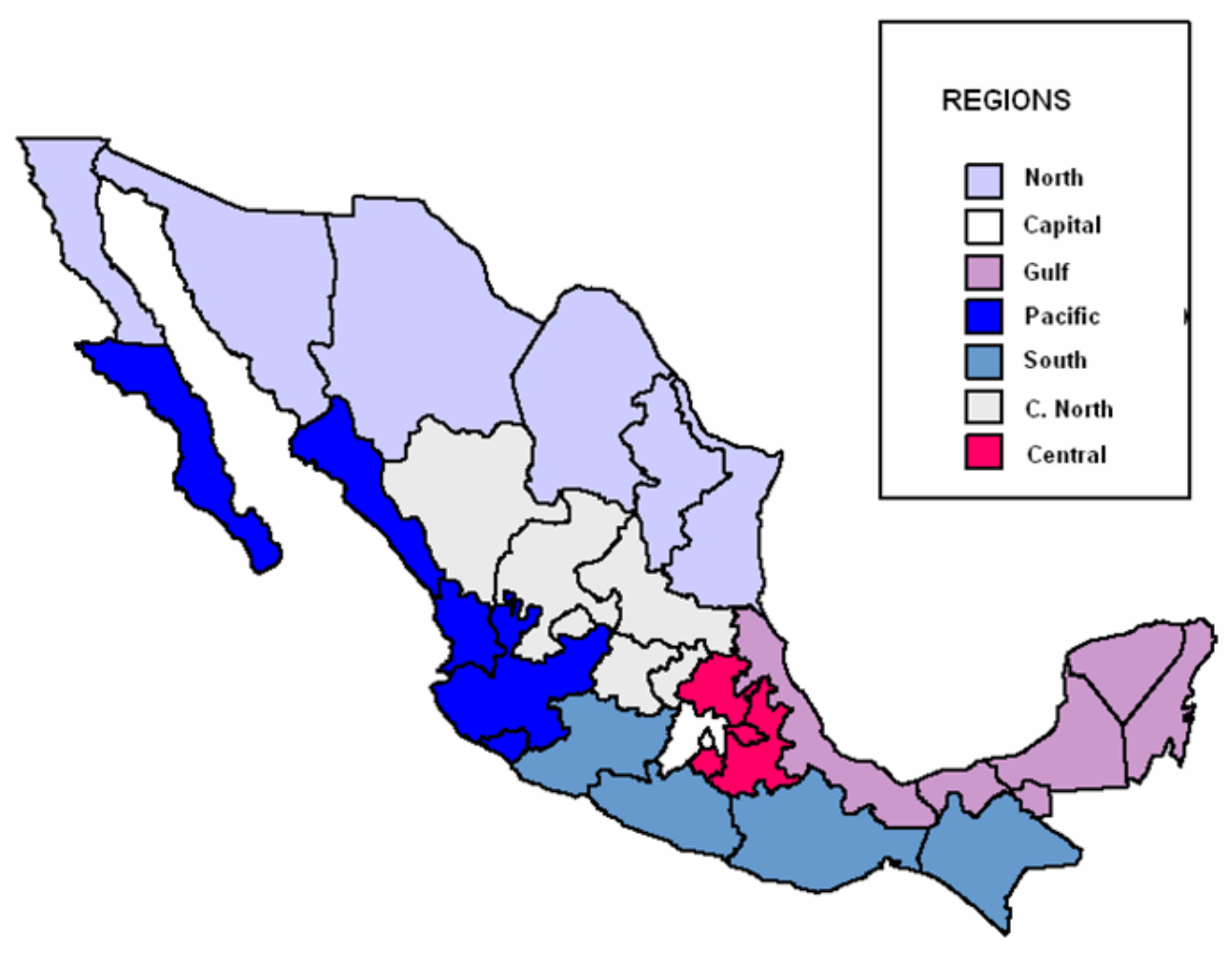




\begin{abstract}
This paper analyzes the labor markets in rural and semi-urban Mexico. The empirical analyses show that nonfarm income shares increase with overall consumption levels and, also, with time. Rural-dwellers in lower quintiles of the consumption distribution tend to earn a larger share of their nonagricultural incomes from wage labor activities. For the poorest, low-productivity wage labor activities are important. The quantile wage regression analysis for rural Mexico shows a rather heterogeneous impact pattern of individual characteristics across the wage distribution on monthly wages. The findings reveal that education is key to earning higher wages and that workers in more dispersed rural areas earn less than their peers in semi-urban rural areas (localities with less than 15,000 inhabitants). The rural nonfarm sector is heterogeneous and includes a great variety of activities and productivity levels across nonfarm jobs. Moreover it can reduce poverty in a couple of distinct but qualitatively important ways in rural Mexico. The analysis of nonfarm employment in rural Mexico, suggests that the two key determinants of access to employment and productivity in nonfarm activities are education and location.
\end{abstract}




\section{Introduction}

Rural labor markets are a subject of widespread interest mainly because of the large number of rural population in the western hemisphere and the ways in which the rural population migrates and exports their produce. In Mexico alone, there are some 25 million rural people, most of them living in poverty.

The agricultural sector contributes just 5 percent to Mexico's GDP while it provides employment to 45 percent of the rural workers in semi-urban areas (localities with rural population less than 15,000) and 56 percent in more dispersed rural areas (locations with less than 2,500 inhabitants). However, labor productivity and returns tend to increase as production shifts from grains to more export oriented crops such as fruits and vegetables, which has occurred in the last decade in Mexico. Moreover, export oriented crops also give a boost to rural nonfarm sector employment.

Today's rural population in Mexico is no longer dependent on agricultural income alone. The rural population receives its income from various sources apart from agricultural activities, namely from off-farm or nonagricultural activities, remittances, and transfers. Moreover, the share of off-farm, transfers and remittances in total income is rapidly increasing for the rural population (see Verner 2004). Labor is the most important asset the poor have and nonagricultural jobs pay the highest wages in rural areas.

Households and locations operate in multiple, interacting activities and sectors, for example rural nonfarm and agriculture are complements and migration affects dynamics at the household and community levels. This has implications for policy because it requires a policy approach that is territorial in a double sense: it takes account of spatial differences and spatial interactions; and it recognizes multiple activities.

This paper tries to shed some empirical light on income generation and employment in the rural agricultural and nonagricultural sectors in Mexico. The analyses are based on ENIGH (Encuesta nacional de Ingresos y Gastos de los Hogares) surveys from 1992 to 2002 and ENET (Encuesta Nacional de Empleo) surveys from 1995 to $2003^{2}$. Rural poverty in Mexico is analyzed in depth in Verner (2005).

This paper is organized as follows. Section 2 addresses developments of the rural labor force, main changes in sectoral employment patterns, labor force characteristics,

\footnotetext{
${ }^{2}$ The National Survey of Employment (Encuesta Nacional de Empleo, or ENE) was first collected in 1996. It contains information about the characteristics of the labor force in Mexico. ENE include variables at the individual level, for example education, hours worked, labor participation, contract type and benefits, social protection coverage, and other basic variables as gender, marital status, and age. Since 2000, ENE incorporates the National Survey of Urban Employment (Encuesta Nacional de Empleo Urbano, or ENEU). Starting in 2000 it became a quarterly survey and is renamed ENET (Encuesta Nacional de Empleo Trimestral) and is reorganized to a panel survey that follows every single individual for 5 quarters. Since the second quarter of 2001, the ENET is representative at the national level, rural and urban level, 48 mayor cities, and Mexico's 32 states.
} 
and rural wages and income composition in the last decade. Section 3 analyzes wage determination and differences in returns across the wage distribution. Section 4 addresses correlates of nonfarm employment and the likelihood of being employed in the high/lowproductivity sectors. Finally, Section 5 concludes and gives policy recommendations.

\section{Rural Labor Markets}

The Mexican rural labor market is important for poverty reduction. Employment is key to lifting poor rural families out of poverty. The rural labor market can be analyzed in many ways. One way is to consider the agriculture and nonagricultural sector or off-farm sector. Rural off-farm employment has traditionally been seen as a low productivity sector, producing low quality goods. The sector, in this view, is expected to shrink as the economy develops and incomes increase. However, recent research shows that this view can be very socially costly. For example, the rural nonfarm sector has a positive role in absorbing a growing rural labor force and slowing rural-urban migration. Moreover, the nonagricultural sector contributes to national income growth and to promote a more equitable distribution of income (see Lanjouw and Lanjouw 2001).

Lanjouw and Lanjouw (2001) also finds that the nonagricultural sector is large and growing in developing countries. In Latin America alone, 47 percent of the labor force in rural settlements and rural towns are employed in off-farm activities. Moreover, 79 percent of women in the Latin American rural labor force are employed in off-farm activities.

Araujo, de Janvry and Sadoulet (2003) measures the role of social networks on behavior applied to rural off-farm employment in Mexico. The authors find that income from off-farm sources is especially important for rural households, and explore the determinants of participation in off-farm nonagricultural employment using data for rural Mexico. In particular, they seek to understand the role of social networks on the individual decision to participate in off-farm labor markets. Araujo et al. find that neighbors' participation in off-farm nonagricultural employment has a significant impact on the individual choice of occupation, even after controlling for availability of opportunities. The role of neighbors' employment choices is more important for groups that are less likely to participate in nonagricultural rural employment such as women, indigenous, the elder, and land-owners. This finding suggests an important role for networks and referrals in the job-search process of rural households. Finally, relative to endowments such as education that are relatively scarce in rural Mexico, Araujo et al finds that social networks compensate more to those who are less endowed and therefore less likely to participate in off-farm nonagricultural employment.

\section{Demographics}

In 2000, more than 25 million of Mexico's total of 97.5 million people lived in rural areas, defined as localities with less than 2,500 inhabitants. The population is slowly moving to urban areas. In 2000, 25 percent of the Mexicans lived in rural areas, 
down from 34 percent two decades earlier. The rural population is not distributed equally throughout the country. For example, in the South region, nearly 47 percent of the population lives in rural areas, a total of more than 6.8 million people. Mexico's rural population increased by 0.6 percent per year during the 1990s. Not all regions followed the same population growth pattern of the total country. In the North region, the rural population actually diminished by 0.1 percent annually during 1990-2000. In the Capital region, the difference in the population growth rate between rural and urban areas was the smallest in Mexico and the rural population expanded at 1.5 percent annually. The population growth rates in the poor South and Gulf regions were in line with the national average during the last decade.

The demographic change that demands the most urgent policy response is the growth in the economically active population in rural areas. During 1990-2000 the number of those aged 12 to 64 rose by more than 300,000 ( 0.6 percent). The growth rate is low primarily due to out-migration. Migration is important in rural Mexico. Mostly young people leave their village in search for employment and find work in a wide variety of economic sectors, either in Mexico or in the U.S. Personal contacts and social networks are decisive factors in the search for work. Of the 2.3 million hired farm workers in Mexico, around 1.4 million are migrants, most of whom range in age from the early 20's to the mid-30's. The migration of farm workers within Mexico follows three main routes, generally from communities of origin in the south to farm operators in the north. Along the Pacific coast, migrants work seasonally in the production of fruits and sugar cane, and year-round in vegetable production. In North-Central Mexico migrant workers help produce key crops such as cotton, apples, and various vegetables (primarily between August and January). Along the Gulf coast, farm operators employ migrants to produce sugar cane, cotton, oranges, and coffee, except during July-September. Moreover, migrant workers send money back to their families and these remittances accounted for more than 10 percent of total household income in 2002 (Verner 2004).

Poverty analyses reveal that many rural workers in Mexico, particularly those in the informal sector and agriculture, are poor. The challenge of creating employment is therefore not only to provide new jobs for the new entrants to the labor force, but also to increase the number of jobs that are able to provide sufficient income to lift the employee's household out of poverty or cushion against it. Creating jobs regardless of quality is not enough-people need good jobs. As the labor market, particularly the informal one, is relatively flexible, the worry is about generating sufficient income via employment rather than simply having a job. Since 1999 the trend in this regard is encouraging as reflected by the recent increasing real wages of unskilled workers (with incomplete or no education) - (see below).

\section{Agriculture, Land, and Rural Living}

Although nearly half of Mexico's total land area is officially classified as agricultural, only 12 percent of the total area is cultivated. This is one of many factors driving migration and off-farm employment in rural Mexico. In the early 1990s, 80 
percent of Mexico's cultivated land required regular irrigation. Because of the high cost of irrigation, the government has emphasized expanding production on existing farmland rather than expanding the area under irrigation. Although corn is grown on almost half of Mexico's cropland, the country became a net importer of grain during the 1970s.

Agricultural practices in Mexico range from traditional techniques, such as the slash-and-burn cultivation of indigenous plants for family subsistence, to the use of advanced technology and marketing expertise in large-scale, capital-intensive export agriculture. Government extension programs have fostered the wider use of machinery, fertilizers, and soil conservation techniques. These diverse agricultural practices call for a diverse rural labor market.

\section{The Labor Force}

The analysis now turns to an examination of data on economic activity and occupation in order to obtain a "snapshot" overview of the farm and nonfarm sector in rural Mexico during the 1990s and early 2000s. The analyses are based on ENE survey data.

The share of the workforce in the formal sector experienced a large long-run decline from the late 1980s to the mid-1990s, followed by a partial recovery in the late 1990s, while the 1994/95 crisis and the 2000/02 period of stagnation tended to increase both unemployment and informality. Since 1995, Mexico's rural workforce has decreased by 0.5 million reaching around 9.3 million in 2003; of these 9.2 were employed, down by 0.3 million since 1995 (see Appendix A). The main explanation is migration of the younger age cohorts to urban areas or abroad. This is causing an increase in the average age of the work force (Table 2.2). ${ }^{3}$ Women, according to data, comprise a relatively small part of Mexico's rural workforce; only 27.0 percent are women (calculations based on ENE 2003 survey). However, this estimation is likely to under-represent the female share of the work force. The way the question is phrased may lead some women to say that they are not part of the work force when they actually are.

Mexico's seven regions each followed their own individual rural labor force development path (see Figure 2.1 and Appendix A). The Pacific and Center-North regions experienced a rapid increased in job creation since 1995. During 1995-2003, the labor force decreased in the Center, Gulf, North, and South regions and in the latter by far the most (around 400,000 workers). The Center-North and Pacific regions experienced their work forces increase by around 200,000 and 400,000 workers, respectively. The increase in the production of export crops in these regions has increased the demand for labor and workers from other parts of Mexico and workers have migrated to grasp the increased opportunity to improve their livelihood.

\footnotetext{
${ }^{3}$ The rural Mexican labor force is defined as people above 12 years of age and living in areas with less than 2,500 inhabitants.
} 
Figure 2.1: Rural Labor Force by Region in Mexico, Selected Years 1995-2003


Source: ENE 1995-2003, $2^{\text {nd }}$ quarter. 
In rural Mexico the employment rate increased during 1999-2003, more specifically, after the sharp increase in unemployment followed by the peso crisis in 1994/95. The sharpest decline in employment occurred between 1995-1996 and it declined until 1999. All five regions experienced a reduction in the number of employed in the 1990s. A large part of the unemployed was absorbed in the informal sector therefore the unemployment rate is relatively small in rural Mexico ( 0.7 percent). However, it is clear that the underemployment rate is very high and according to some estimates reaches more than 20 percent of the active population. ${ }^{4}$

The entire economic active population in rural areas with less than 2,500 inhabitants is broken down by sector of principal activity (occupation) in Table 2.1. In rural Mexico, 56 percent of the working population was engaged in agricultural activities in 2003 and the vast majority in cultivation. Moreover, the greater part consists of males, 66.9 and 25.0 percent of the rural males and females were employed in agricultural activities, respectively in 2003 (Table 2.2). Agricultural employment fell from 63 percent in 1995 primarily due to increased urbanization absorbing labor. Agriculture still employs a large share of the population in the southern states, which have a relatively high level of poverty and a large indigenous population. Even in urban areas 5.4 percent of the working population were engaged in agricultural activities as a principal occupation in 2003. Labor markets are highly seasonal in Mexican agriculture. Many rural workers are employed part-time in agriculture and work the rest of the time in nonagricultural sectors such as construction, manufacturing, and services, particularly in the Southern states where there is only one crop-growing season due to limited infrastructure for irrigation.

Turning to rural nonfarm activities, it can be observed that 18.5 percent of the working age population were primarily engaged in manufacturing, 10 percent in sales, and 16 percent in various service sector activities in 2003 (Table 2.1). In total, about 44 percent of the rural working population was engaged in nonagricultural activities as a primary activity. These estimates are likely to be conservative estimates of the importance of nonagricultural activities because they do not include nonfarm activities that are secondary. Moreover, when changing the definition of rural to localities with less than 15,000 inhabitants then 55 percent of the rural workers were employed in the nonfarm sector.

Focusing on the nonagricultural working population in the rural areas with less than 2,500 inhabitants the information in Table 2.1 reveals that the most important activities manufacturing subsectors comprise construction, food processing, and clothing. Personal services, education, and hotel and restaurant are the most important service subsectors. Employment rates in the government sector accounts for only a small fraction of total nonfarm employment in rural areas ( 2 percent). Government employment in urban areas accounts for nearly triple that of rural areas (5.8 percent). Nonagricultural incomes accrue to rural households through nonagricultural wage labor, home enterprises, conditional-cash transfers, and remittances.

\footnotetext{
${ }^{4}$ Source: Oxford Analytica, April 2004.
} 


\begin{tabular}{|c|c|c|c|c|c|c|c|c|}
\hline \multicolumn{9}{|c|}{ Table 2.1: Share of Working Population by Sector of } \\
\hline & \multicolumn{4}{|c|}{$\begin{array}{cc}\text { Labor Composition } & \begin{array}{c}\text { Mean Hourly Wage } \\
\text { (Pesos) }^{\text {c }}\end{array}\end{array}$} & \multicolumn{2}{|c|}{ Labor Composition } & \multicolumn{2}{|c|}{$\begin{array}{l}\text { Mean Hourly Wage } \\
\text { (Pesos) }\end{array}$} \\
\hline & Urban & Rural $^{\mathrm{b}}$ & Urban & Rural & Urban & Rural & Urban & Rural \\
\hline Agriculture & 9.63 & 62.82 & 12.04 & 8.30 & 5.40 & 55.61 & 13.46 & 7.44 \\
\hline Cultivation & 7.71 & 53.75 & 11.40 & 7.79 & 4.25 & 43.38 & 12.92 & 6.76 \\
\hline Animal rearing & 1.35 & 5.13 & 14.47 & 9.18 & 0.69 & 6.02 & 14.30 & 9.30 \\
\hline Forest product & 0.09 & 1.02 & 11.98 & 13.35 & 0.04 & 1.27 & 12.12 & 9.44 \\
\hline Fishing & 0.47 & 2.92 & 13.17 & 11.37 & 0.41 & 4.95 & 16.74 & 11.10 \\
\hline 1 Mining/extraction & 0.34 & 0.68 & 18.63 & 12.67 & 0.39 & 0.13 & 36.55 & 16.59 \\
\hline 2 Manufacturing & 24.75 & 11.05 & 17.14 & 11.78 & 26.26 & 18.51 & 19.07 & 12.35 \\
\hline Food processing & 3.26 & 1.23 & 14.11 & 13.11 & 3.75 & 3.22 & 16.57 & 10.85 \\
\hline Beverages & 0.69 & 0.18 & 15.12 & 13.93 & 0.68 & 0.18 & 19.69 & 10.51 \\
\hline Tobacco products & 0.05 & 0.02 & 21.11 & 14.19 & 0.01 & 0.00 & 26.86 & \\
\hline Textiles & 0.74 & 0.87 & 15.75 & 10.13 & 0.98 & 0.94 & 15.88 & 7.14 \\
\hline Clothing & 2.05 & 1.44 & 13.91 & 9.53 & 2.24 & 2.44 & 14.55 & 9.20 \\
\hline Leather & 0.19 & 0.00 & 17.08 & 9.08 & 0.14 & 0.11 & 22.37 & 8.64 \\
\hline Footwear & 0.61 & 0.04 & 15.05 & 8.75 & 0.52 & 0.01 & 19.58 & 7.51 \\
\hline Wooden goods & 0.48 & 0.45 & 18.16 & 10.44 & 0.44 & 1.08 & 17.95 & 9.22 \\
\hline Furniture & 0.91 & 0.62 & 14.72 & 11.84 & 0.95 & 0.82 & 18.45 & 12.78 \\
\hline Paper & 0.39 & 0.08 & 16.01 & 10.91 & 0.35 & 0.11 & 18.27 & 12.83 \\
\hline Printing & 0.91 & 0.06 & 17.81 & 18.00 & 0.72 & 0.02 & 21.31 & 13.36 \\
\hline Chemical & 0.86 & 0.21 & 26.03 & 15.06 & 0.48 & 0.03 & 31.87 & 19.80 \\
\hline Plastic/rubber & 0.81 & 0.16 & 20.73 & 12.03 & 0.77 & 0.13 & 18.48 & 12.93 \\
\hline Ceramic/cement & 1.08 & 0.55 & 17.97 & 8.70 & 0.83 & 1.13 & 18.03 & 12.28 \\
\hline Pharmaceuticals & 0.22 & 0.00 & 27.21 & & 0.20 & 0.02 & 32.99 & 24.36 \\
\hline Cosmetics & 0.26 & 0.00 & 15.75 & & 0.23 & 0.09 & 17.80 & 11.56 \\
\hline Metals & 0.38 & 0.04 & 23.06 & 17.40 & 0.26 & 0.03 & 24.10 & 16.96 \\
\hline Machinery & 1.98 & 0.21 & 17.75 & 11.32 & 2.07 & 0.55 & 19.92 & 15.47 \\
\hline Electronic goods & 1.08 & 0.12 & 16.66 & 9.49 & 1.17 & 0.08 & 19.94 & 13.34 \\
\hline Vehicles & 1.39 & 0.10 & 17.39 & 15.09 & 1.51 & 0.49 & 20.31 & 14.29 \\
\hline Precision instruments/others & 0.43 & 0.03 & 19.31 & 13.04 & 0.56 & 0.09 & 18.11 & 16.44 \\
\hline Construction & 5.68 & 4.59 & 17.28 & 12.46 & 6.75 & 6.81 & 19.61 & 14.53 \\
\hline Utilities & 0.31 & 0.05 & 26.80 & 19.34 & 0.66 & 0.12 & 26.75 & 18.31 \\
\hline 3 Sales & 21.15 & 11.66 & 16.60 & 10.78 & 21.54 & 9.97 & 17.16 & 10.53 \\
\hline Wholesaling & 3.05 & 0.72 & 21.49 & 12.72 & 3.33 & 0.70 & 21.25 & 13.01 \\
\hline Formal sales & 14.33 & 8.99 & 15.36 & 10.09 & 18.21 & 9.27 & 16.33 & 10.30 \\
\hline Street sales & 3.77 & 1.95 & 16.66 & 12.67 & 0.00 & 0.00 & 0.00 & 0.00 \\
\hline 4 Services & 44.14 & 13.79 & 21.74 & 13.94 & 46.41 & 15.77 & 23.02 & 14.13 \\
\hline Hotel/Restaurant & 5.74 & 1.60 & 15.37 & 11.26 & 6.31 & 2.32 & 16.99 & 12.18 \\
\hline Transport & 4.78 & 1.84 & 18.21 & 13.82 & 4.88 & 1.56 & 19.99 & 14.28 \\
\hline Communications & 0.46 & 0.13 & 25.83 & 14.48 & 0.58 & 0.06 & 27.58 & 9.01 \\
\hline Financial services & 1.25 & 0.04 & 35.14 & 24.38 & 0.90 & 0.03 & 31.19 & 21.16 \\
\hline Professional services & 2.92 & 0.29 & 24.52 & 9.98 & 4.05 & 0.44 & 25.19 & 13.48 \\
\hline Education & 6.15 & 1.78 & 34.73 & 26.40 & 5.89 & 2.13 & 37.70 & 26.28 \\
\hline Arts/entertainment & 1.25 & 0.26 & 22.58 & 16.21 & 1.42 & 0.35 & 25.06 & 16.27 \\
\hline Medical services & 3.06 & 0.47 & 25.28 & 16.55 & 3.41 & 0.64 & 30.13 & 18.07 \\
\hline Servicing/repair & 8.26 & 2.57 & 17.08 & 12.38 & 7.33 & 2.21 & 18.24 & 13.53 \\
\hline Personal services & 4.81 & 2.98 & 12.63 & 10.19 & 5.71 & 3.96 & 14.18 & 9.65 \\
\hline Renting services & 0.23 & 0.05 & 26.09 & 10.81 & 0.25 & 0.02 & 26.33 & 13.94 \\
\hline Government & 5.12 & 1.72 & 24.18 & 12.81 & 5.66 & 2.04 & 27.28 & 15.98 \\
\hline Other & 0.11 & 0.08 & 12.62 & 8.87 & 0.03 & 0.00 & 14.68 & \\
\hline Nonagricultural & & & & & & & & \\
\hline Total $(1+2+3+4)$ & 90.37 & 37.18 & & & 94.60 & 44.39 & & \\
\hline Employed & $24,267,941$ & $9,605,455$ & & & $31,430,834$ & $9,202,363$ & & \\
\hline
\end{tabular}


A further break down of the ENE data is presented in Table 2.2, where we consider among other things, the sector of activity and the participation of women and men separately over time in the rural labor force. Of the working-age population in rural Mexico, the share of people engaging in agricultural activities is slowly falling while the share engaging in nonfarm activities is slowly rising. In 2003 the vast majority of women (75 percent) worked in nonfarm related activities while the majority of men worked in farm related activities (67 percent).

Table 2.2 also reveals information on the labor status of the rural population. In 2003, employers and the self-employed constituted 40.9 and 36.5 percent of the male and female employed, employees 39.3 and 34.2 percent, and unpaid family workers 16.0 and 25.0 percent, respectively. Partly because of high unemployment in the formal labor sector, the number of informal-sector workers ballooned during the 1990s, reaching 27.5 and 17.8 percent of the male and female employees respectively in 2003.

The nonpoor people are relatively more likely to be employed in nonagricultural activities than the poor are (see Verner 2004). While 61.3 percent of the poor working population is employed in nonagricultural activities, more than 78 percent of the nonpoor are active in this sector; up from 42.3 and 50.6 percent respectively in 1992. This may indicate that nonfarm employment offers a route out of poverty in rural Mexico.

The average years of education of the employed 9.3 million people in the rural labor force increased from 4.4 years for both genders in 1995, to 5.1 and 5.4 years for males and females respectively in 2003 (Table 2.2). The level of attained education of the work force is rapidly increasing (Figure 2.2). The male and female workers that completed lower secondary education increased by 62.2 and 83.6 percent, respectively, during 1995-2003. The workers that had completed upper secondary education expanded by 118.5 and 75.3 percent for male and female workers, respectively, although the level is still very low. Only 2.6 and 3.1 percent male and female workers have completed secondary school.

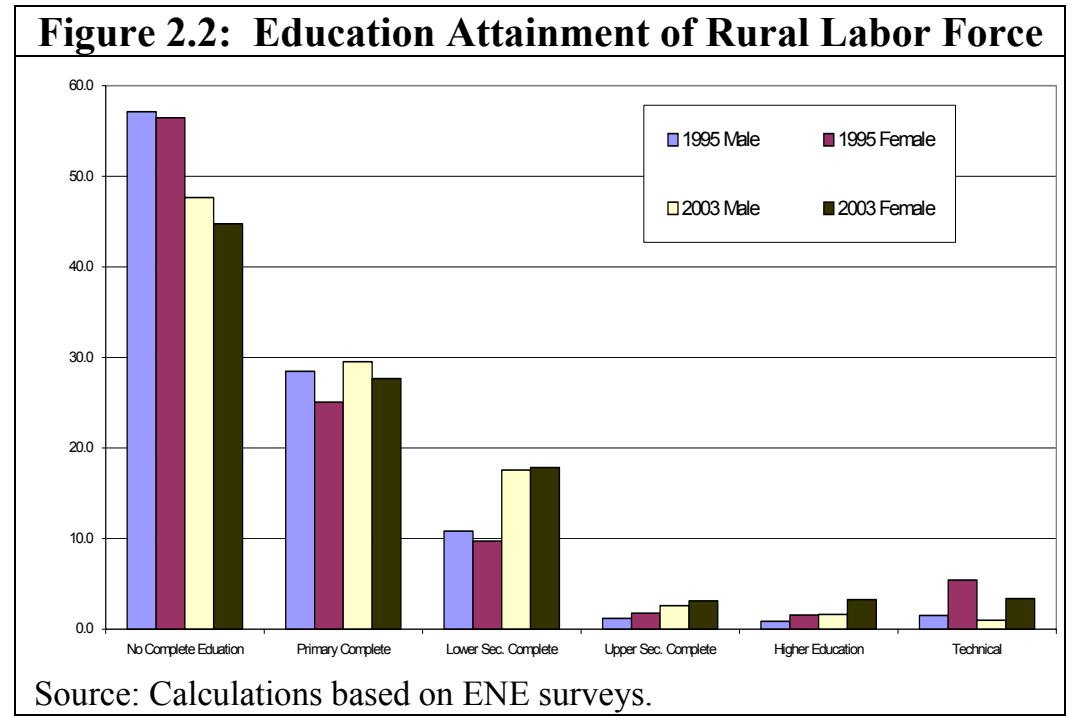




\begin{tabular}{|c|c|c|c|c|c|c|c|c|c|c|c|c|c|c|c|c|}
\hline \multirow[b]{2}{*}{ Variable } & \multicolumn{2}{|c|}{1995} & \multirow{2}{*}{\multicolumn{2}{|c|}{$\begin{array}{c}1996 \\
\text { Male Female }\end{array}$}} & \multirow{2}{*}{\multicolumn{2}{|c|}{$\begin{array}{c}1998 \\
\text { Male Female }\end{array}$}} & \multirow{2}{*}{\multicolumn{2}{|c|}{$\begin{array}{c}1999 \\
\text { Male Female }\end{array}$}} & \multirow{2}{*}{\multicolumn{2}{|c|}{$\begin{array}{c}2000 \\
\text { Male Female }\end{array}$}} & \multirow{2}{*}{\multicolumn{2}{|c|}{$\begin{array}{c}2001 \\
\text { Male Female }\end{array}$}} & \multirow{2}{*}{\multicolumn{2}{|c|}{$\begin{array}{c}2002 \\
\text { e Male Female }\end{array}$}} & \multirow{2}{*}{\multicolumn{2}{|c|}{$\begin{array}{c}2003 \\
\text { Male Female }\end{array}$}} \\
\hline & Male & e Female & & & & & & & & & & & & & & \\
\hline \multicolumn{17}{|c|}{$\begin{array}{l}\text { GENERAL LABOR FORCE STRUCTURE } \\
\text { EMPLOYED }\end{array}$} \\
\hline Mean Age & 34.8 & 33.6 & 34.8 & 33.5 & 35.5 & 33.8 & 35.6 & 34.5 & 36.4 & 34.3 & 37.3 & 35.0 & 37.6 & 36.0 & 37.9 & 36.3 \\
\hline Years of Schooling & 4.4 & 4.4 & 4.6 & 4.7 & 4.8 & 5.0 & 4.8 & 4.9 & 5.0 & 5.2 & 4.9 & 5.1 & 5.0 & 5.2 & 5.1 & 5.4 \\
\hline Hours worked per week & 40.8 & 29.3 & 43.4 & 31.5 & 41.7 & 30.7 & 43.7 & 31.8 & 41.7 & 31.4 & 40.7 & 30.9 & 41.0 & 32.2 & 40.0 & 31.5 \\
\hline \multicolumn{17}{|l|}{ LABOR STATUS } \\
\hline Employer & 3.7 & 1.1 & 4.9 & 1.6 & 2.7 & 0.9 & 2.7 & 0.9 & 2.7 & 0.6 & 3.5 & 1.0 & 3.2 & 1.1 & 3.1 & 1.0 \\
\hline Self-employed & 36.3 & 29.0 & 36.7 & 26.4 & 37.2 & 29.0 & 38.0 & 29.7 & 37.2 & 30.2 & 38.1 & 34.2 & 37.3 & 34.8 & 37.8 & 35.5 \\
\hline Informal Salaried & 18.7 & 13.9 & 18.7 & 15.4 & 20.7 & 15.9 & 22.4 & 14.8 & 23.0 & 16.5 & 24.7 & 16.1 & 26.2 & 17.7 & 27.5 & 17.8 \\
\hline Formal Salaried & 9.2 & 10.0 & 8.6 & 9.1 & 9.3 & 9.1 & 8.8 & 9.9 & 9.4 & 10.8 & 9.8 & 13.2 & 9.2 & 10.5 & 8.1 & 12.5 \\
\hline Contract & 5.0 & 2.8 & 3.8 & 3.7 & 4.7 & 4.2 & 3.4 & 4.5 & 5.2 & 6.4 & 3.8 & 5.0 & 3.5 & 4.5 & 3.8 & 3.9 \\
\hline Family Worker & 20.8 & 39.5 & 21.3 & 39.5 & 20.4 & 35.3 & 19.5 & 35.2 & 16.4 & 30.2 & 15.6 & 26.2 & 16.8 & 26.3 & 16.0 & 25.0 \\
\hline Other & 6.4 & 3.8 & 6.0 & 4.3 & 5.1 & 5.7 & 5.1 & 5.0 & 6.1 & 5.3 & 4.5 & 4.4 & 3.8 & 5.1 & 3.8 & 4.3 \\
\hline \multicolumn{17}{|l|}{ SECTOR OF ACTIVITY } \\
\hline Agriculture & 71.6 & 37.7 & 71.7 & 40.9 & 68.8 & 34.3 & 71.5 & 36.1 & 66.7 & 29.1 & 68.8 & 26.0 & 68.5 & 27.4 & 66.9 & 25.0 \\
\hline Industry & 12.3 & 10.1 & 13.9 & 15.9 & 15.7 & 20.4 & 13.4 & 20.5 & 17.7 & 25.1 & 16.2 & 27.2 & 15.4 & 23.7 & 16.8 & 23.6 \\
\hline Services & 16.0 & 52.1 & 14.4 & 43.2 & 15.5 & 45.3 & 15.1 & 43.4 & 15.6 & 45.7 & 15.0 & 46.9 & 16.1 & 48.9 & 16.3 & 51.4 \\
\hline \multicolumn{17}{|c|}{ LABOR FORCE EDUCATION STATUS } \\
\hline No education/Primary Incomplete & 57.1 & 56.5 & 54.7 & 54.3 & 52.7 & 51.0 & 52.8 & 51.1 & 51.5 & 48.8 & 51.2 & 48.0 & 49.4 & 46.4 & 47.7 & 44.8 \\
\hline Primary Complete & 28.5 & 25.1 & 28.7 & 27.0 & 29.9 & 28.9 & 29.0 & 27.9 & 29.3 & 28.1 & 28.7 & 28.7 & 29.2 & 28.5 & 29.5 & 27.7 \\
\hline Lower Sec. Complete & 10.8 & 9.7 & 12.1 & 10.9 & 12.9 & 12.3 & 14.1 & 12.6 & 14.2 & 14.4 & 14.8 & 14.9 & 16.0 & 16.1 & 17.6 & 17.8 \\
\hline Upper Sec. Complete & 1.2 & 1.8 & 1.7 & 1.4 & 2.1 & 2.0 & 2.0 & 2.3 & 2.4 & 2.7 & 2.4 & 2.6 & 2.7 & 3.1 & 2.6 & 3.1 \\
\hline Higher Education & 0.9 & 1.6 & 1.2 & 2.0 & 1.1 & 1.8 & 1.0 & 1.9 & 1.5 & 2.0 & 1.5 & 2.3 & 1.5 & 2.5 & 1.7 & 3.3 \\
\hline Technical & 1.5 & 5.4 & 1.7 & 4.4 & 1.3 & 3.9 & 1.0 & 4.2 & 1.0 & 3.8 & 1.4 & 3.6 & 1.2 & 3.5 & 1.0 & 3.4 \\
\hline
\end{tabular}




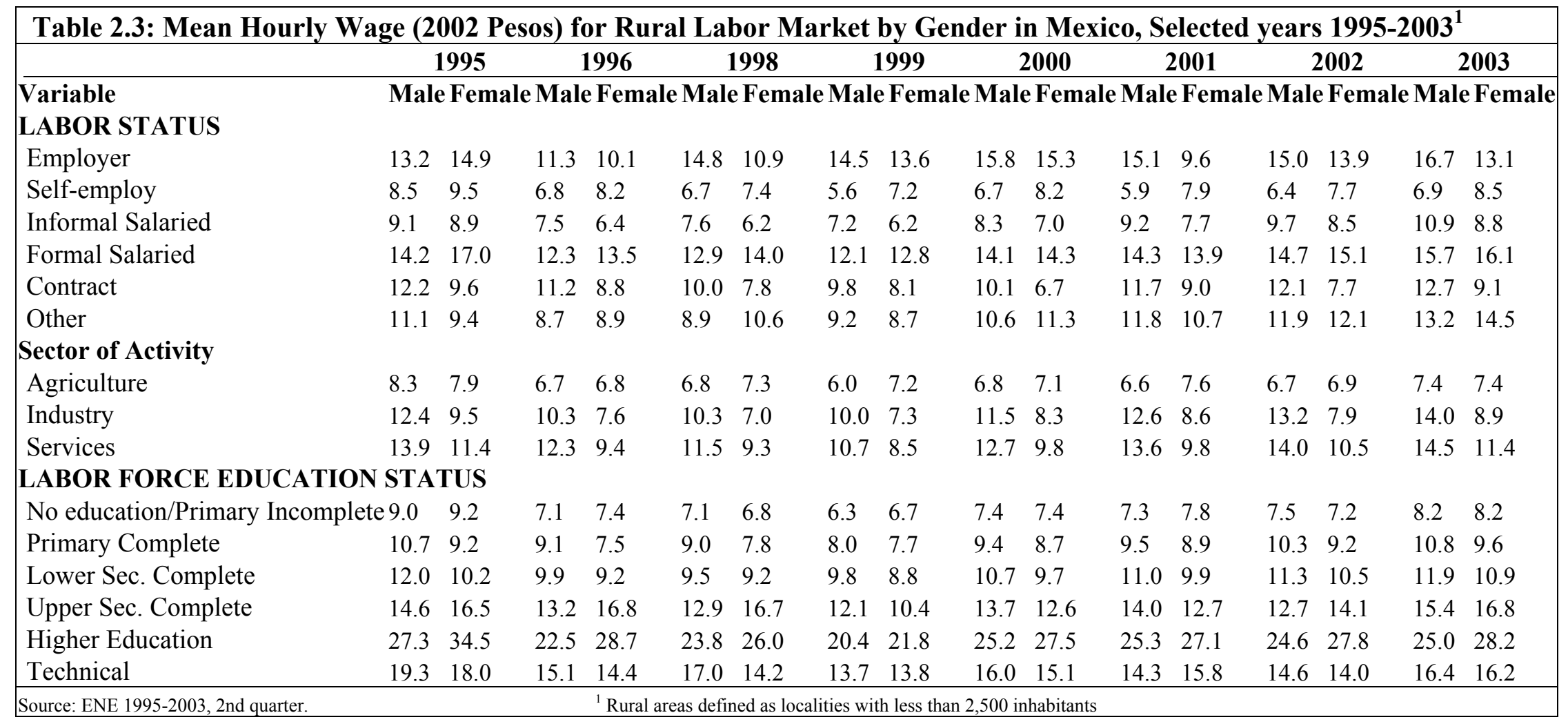


The labor force is aging in rural Mexico. In the last decade the average age increased and that is mainly due to out migration of the people in their 20's and early 30 's. In the work force, men are slightly older than women; the average age reached 37.9 and 36.3 for men and women respectively in 2003. Moreover, on the job, men work around 24 percent more hours per week than women, reaching 40 hours weekly (Table 2.2).

\section{Wages}

The average real wage in Mexico remained relatively low during the last decade, both in historical and international perspective. The Confederation of Mexican Workers (Confederación de Trabajadores Mexicanos--CTM) noted that the average worker's purchasing power in 2003 was only around 60 percent of its 1982 level. ${ }^{5}$

Although the government increased the minimum wage by 21 percent during 1995 , the cost of living rose by more than 50 percent as a result of the currency collapse. In September 1995, the minimum wage was sufficient to cover only 35 percent of workers' basic necessities, compared to 94 percent in December 1987. The government's anti-inflation APRE program called for the minimum wage to increase in line with projected inflation of 21 percent.

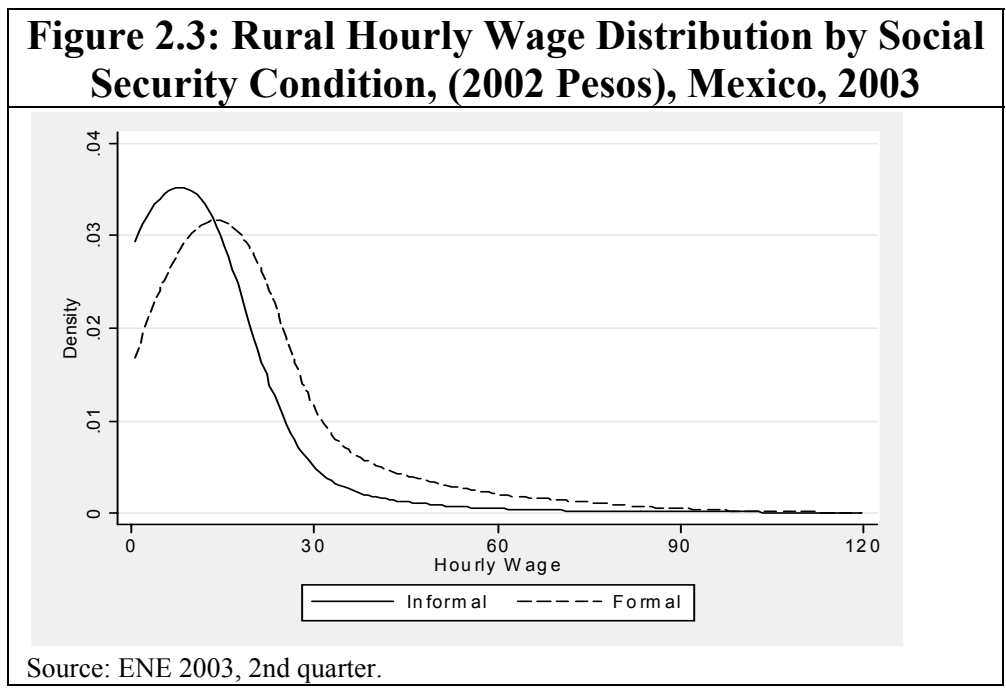

\footnotetext{
${ }^{5}$ Source: http://countrystudies.us/mexico.
} 
Employer wages are significantly higher than those of self-employed, and informal employees but in line with wages of formal sector employees (Table 2.3). Figure 2.3 shows the hourly wage distribution for the formal and informal sector workers for 2003, a picture that remained unchanged during 1995-2003. Formal sector workers are defined as workers that make contributions to social security, etc. and therefore are protected. The graph shows clearly that median wages are higher in the formal sector and this picture did not change during 1995-2003. Not only do protected formal sector workers receive benefits and other social services, but also the average hourly wage is larger than for unprotected informal workers.

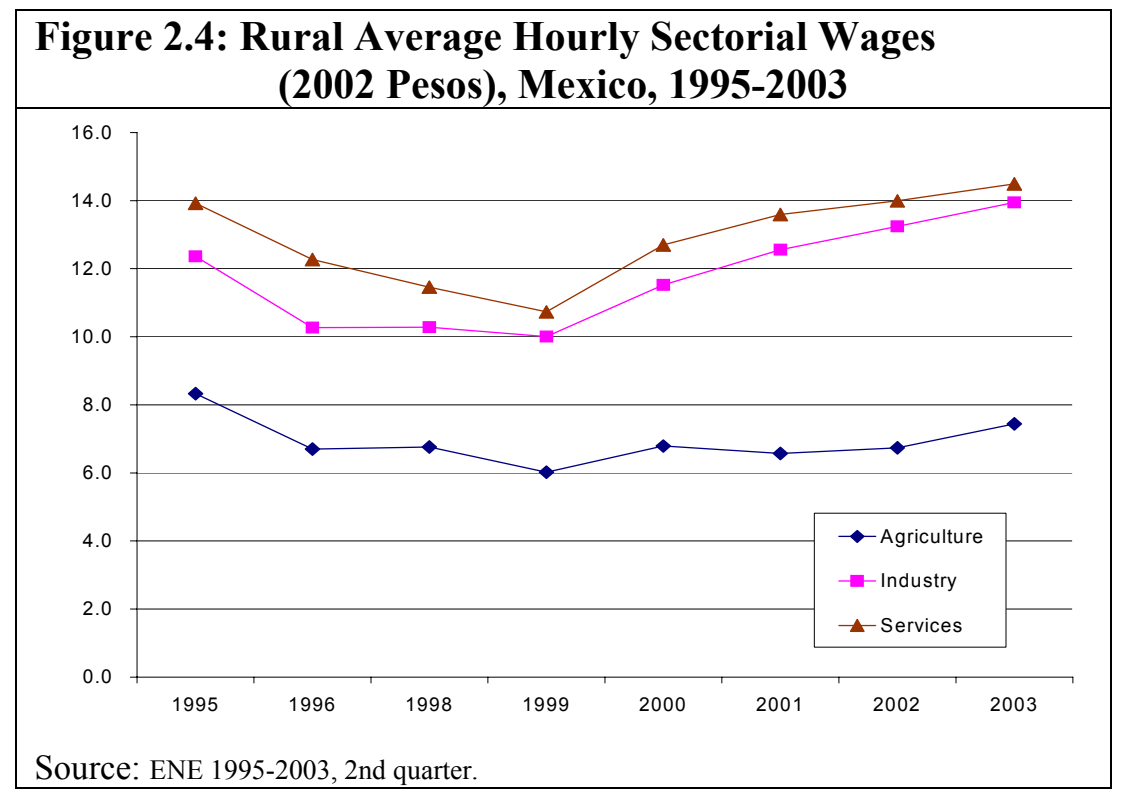

The average hourly wages in the three sectors agriculture, industry, and services followed the same downward trend as unemployment from 1995-99 (see Figure 2.4) indicating a small trade-off between unemployment and wages in the rural labor market. In this period, agriculture, industry, and service wages fell 27.7, 19.1, and 22.9 percent, respectively. Although agricultural wages fell the most, they did not pick up as fast as the other sectors during the general average hourly wage upswing in 1999-2003. In this period, agriculture, industry, and service wages increased 26.6, 39.4, and 35.0 percent, respectively, leaving agriculture hourly wages 19.1 percent below their 1995 level. Considering the whole distribution of hourly wages for the three sectors, median wages are higher in the nonagricultural sector, but the distribution shows a thicker right tail indicating that more people are being paid higher wages in agriculture than in other sectors. This picture did not change significantly during 1995-2003 (see Figure 2.5). 


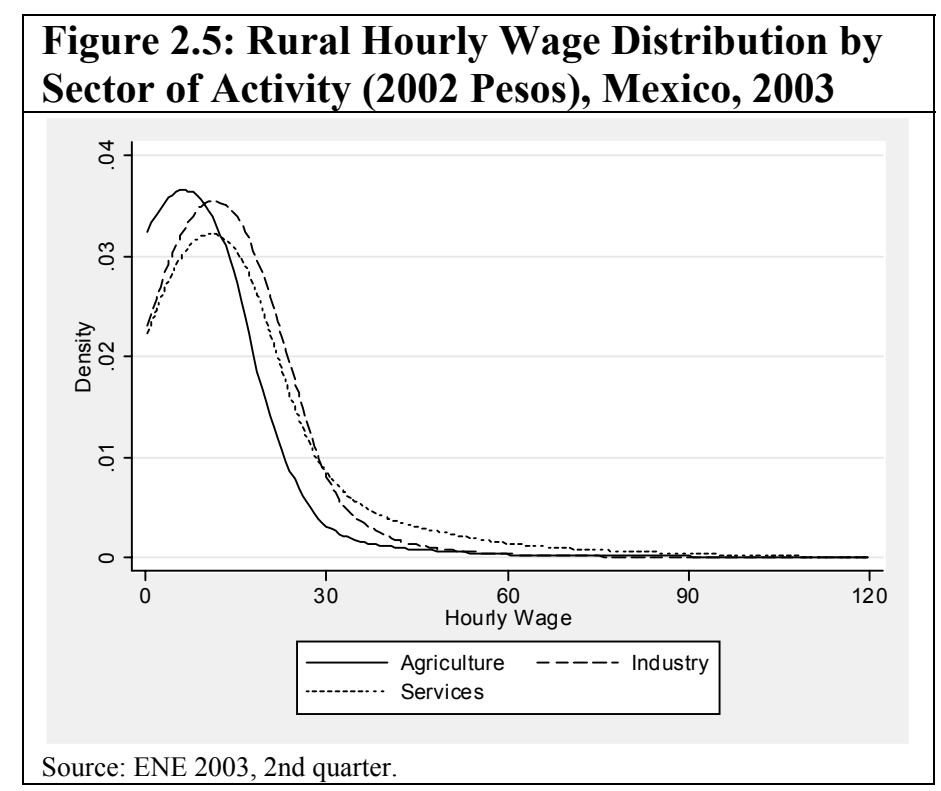

Off-farm labor income is the most important income source for the rural population in Mexico. The share of off-farm labor income has increased its share of total income from 49 percent in 1992 to 66 percent in 2002 (see Figure 2.6 and Table 2.5). The high-productivity nonfarm income share increased nearly five-fold, while the low productivity income share fell during 1992-2002. In 1992, none of the seven regions had high productivity rural nonfarm income shares accounting for more than 7.5 percent of total income. Over the past decade these shares reached 51, 22, and 21 percent in the Pacific, Capital, and Gulf regions, respectively. In the Center and South region, the highproductivity rural nonfarm income share is still low, reaching only 5.6 and 9.9 percent respectively in 2002 .

The farm-income share of total rural income fell dramatically during 1992-2002 according to the 1992-2002 ENIGH surveys (Table 2.4 and Figure 2.6). The share of agricultural income in total rural income fell from 50.8 percent in 1992 to 23.8 percent in 2002. The regions that experienced the largest reduction in the agricultural income share were the North, Capital, and Pacific regions with close to a 70 percent reduction in the agricultural income share. The South and Center regions experienced the lowest reduction, namely 38 and 30 percent, respectively. The South region still has the largest agricultural income share of all regions, reaching 41.2 percent in 2002 . 


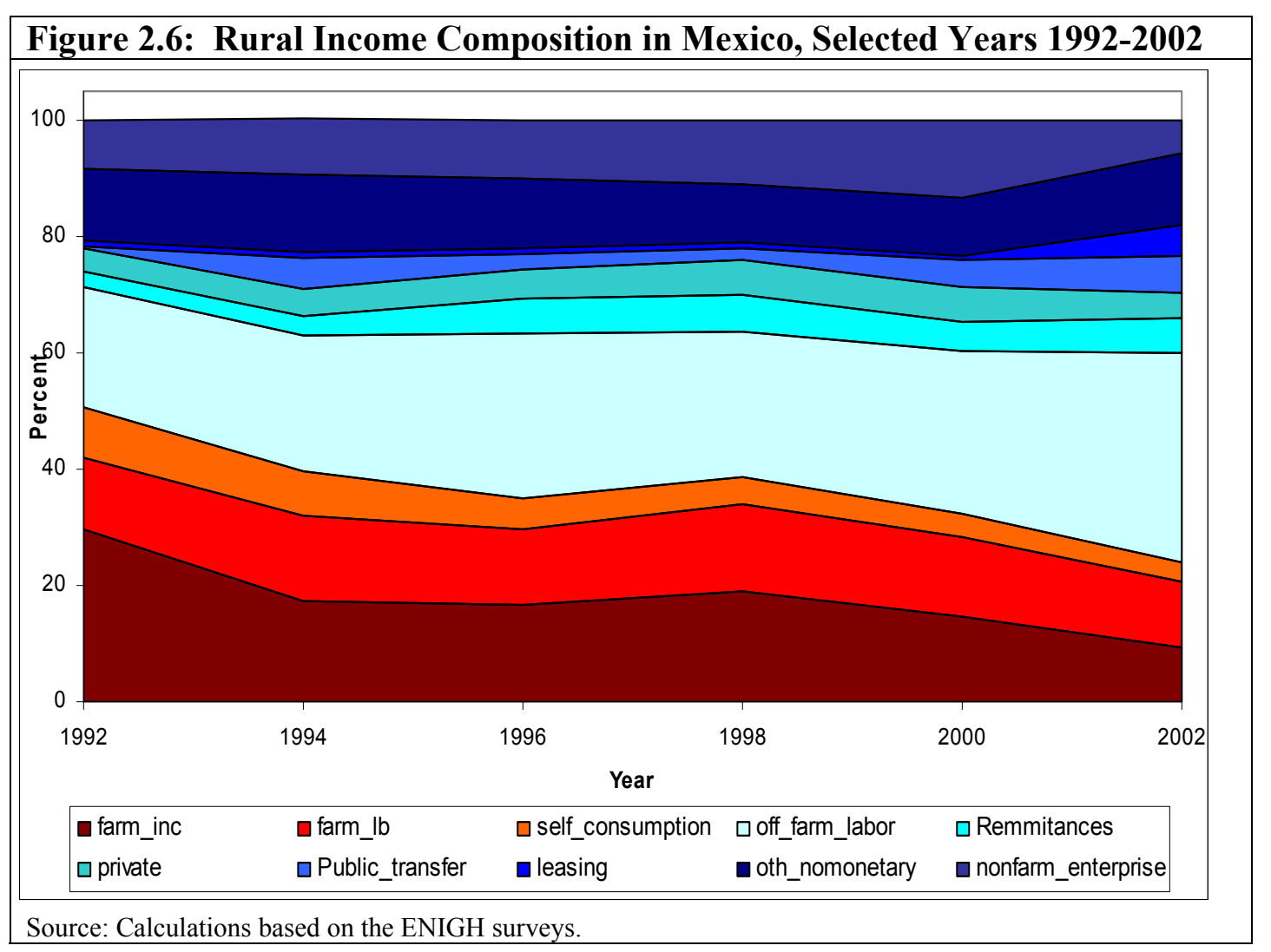

Table 2.4: Agricultural Income Shares by Source and Region, Rural Mexico 1992 and 2002

\begin{tabular}{|c|c|c|c|c|c|c|c|c|c|c|c|c|c|}
\hline & \multicolumn{6}{|c|}{1992} & \multicolumn{7}{|c|}{2002} \\
\hline & $\begin{array}{l}\text { Cultiva } \\
\text {-tion }\end{array}$ & $\begin{array}{l}\text { Farm } \\
\text { enter- } \\
\text { prise } \\
\end{array}$ & $\begin{array}{c}\text { Self - } \\
\text { consump } \\
\text {-tion }\end{array}$ & $\begin{array}{c}\text { Agricul- } \\
\text { tural } \\
\text { labor }\end{array}$ & $\begin{array}{l}\text { Farm } \\
\text { labor }\end{array}$ & $\begin{array}{c}\text { Total } \\
\text { Agricul } \\
\text { ture } \\
\end{array}$ & $\begin{array}{c}\text { Cultiva } \\
\text { tion }\end{array}$ & $\begin{array}{l}\text { Farm } \\
\text { Enter } \\
\text { prise } \\
\end{array}$ & $\begin{array}{c}\text { Self }- \\
\text { consump } \\
\text { tion }\end{array}$ & $\begin{array}{c}\text { Agricul- } \\
\text { tural } \\
\text { Labor }\end{array}$ & $\begin{array}{l}\text { Farm } \\
\text { Labor }\end{array}$ & $\begin{array}{c}\text { Total } \\
\text { Agricul } \\
\text { ture } \\
\end{array}$ & $\begin{array}{c}\text { Change } \\
1991-2002 \\
(\%) \\
\end{array}$ \\
\hline Mexico & 17.9 & 11.9 & 8.7 & 10.2 & 2.1 & 50.8 & 5.1 & 4.4 & 3.1 & 8.0 & 3.3 & 23.8 & -53.1 \\
\hline North & 21.1 & 14.4 & 4.3 & 16.6 & 2.8 & 59.2 & 2.0 & 3.5 & 1.8 & 5.1 & 7.1 & 19.5 & -67.0 \\
\hline Capital & 8.1 & 9.4 & 8.0 & 7.8 & 0.9 & 34.1 & 1.5 & 1.4 & 2.2 & 5.1 & 0.8 & 11.0 & -67.8 \\
\hline Gulf & 20.0 & 9.5 & 7.8 & 6.4 & 4.4 & 48.1 & 3.1 & 1.6 & 1.8 & 10.9 & 4.8 & 22.2 & -53.9 \\
\hline Pacific & 11.0 & 8.7 & 7.1 & 11.6 & 1.8 & 40.3 & 3.4 & 2.7 & 1.3 & 3.7 & 1.3 & 12.4 & -69.2 \\
\hline South & 21.2 & 18.1 & 15.4 & 10.3 & 1.6 & 66.6 & 9.2 & 9.1 & 6.5 & 11.0 & 5.4 & 41.2 & -38.1 \\
\hline $\begin{array}{l}\text { Center- } \\
\text { North }\end{array}$ & 22.2 & 10.9 & 7.2 & 6.6 & 1.0 & 47.8 & 7.4 & 4.7 & 2.5 & 8.5 & 2.2 & 25.4 & -47.0 \\
\hline Center & 9.9 & 6.5 & 6.9 & 15.1 & 0.6 & 38.9 & 4.7 & 4.4 & 4.8 & 12.4 & 1.0 & 27.3 & -29.8 \\
\hline
\end{tabular}


Table 2.5: Nonagricultural Income Sources in Localities with less than 2,500 inhabitants in Rural Mexico, 2002

\begin{tabular}{|c|c|c|c|c|c|c|c|c|c|c|c|c|c|c|c|c|c|}
\hline & $\begin{array}{l}\text { Low-return } \\
\text { Nonfarm } \\
\text { Labor } \\
\text { Income } \\
\end{array}$ & $\begin{array}{l}\text { Nonfarm } \\
\text { Labor } \\
\text { Income }\end{array}$ & $\begin{array}{c}\text { Enterprise } \\
\text { Income }\end{array}$ & Remittances & $\begin{array}{l}\text { Other } \\
\text { Private } \\
\text { Transfer } \\
\text { Income } \\
\end{array}$ & $\begin{array}{l}\text { Public } \\
\text { Transfer } \\
\text { Income }\end{array}$ & $\begin{array}{c}\text { Other } \\
\text { No- } \\
\text { monetary } \\
\text { Income }\end{array}$ & $\begin{array}{c}\text { Total } \\
\text { Nonagri- } \\
\text { cultural } \\
\text { Income }\end{array}$ & $\begin{array}{l}\text { Low-return } \\
\text { nonfarm } \\
\text { Labor } \\
\text { Income } \\
\end{array}$ & $\begin{array}{l}\text { High-return } \\
\text { Nonfarm } \\
\text { Labor income }\end{array}$ & $\begin{array}{l}\text { Nonfarm } \\
\text { Enterprise } \\
\text { Income }\end{array}$ & $\begin{array}{l}\text { Remittances } \\
\text { Income }\end{array}$ & $\begin{array}{c}\text { Other } \\
\text { private } \\
\text { Transfer } \\
\text { Income }\end{array}$ & $\begin{array}{l}\text { PRO- } \\
\text { CAMPO } \\
\text { rTransfer } \\
\text { Income }\end{array}$ & $\begin{array}{l}\text { Public } \\
\text { Transfer } \\
\text { Income }\end{array}$ & $\begin{array}{c}\text { Other } \\
\text { No- } \\
\text { monetary } \\
\text { Income }\end{array}$ & $\begin{array}{c}\text { Total } \\
\text { Nonagricul- } \\
\text { tural } \\
\\
\text { Income } \\
\end{array}$ \\
\hline TOTAL & 15.5 & 4.9 & 8.1 & 2.7 & 4.1 & 0.2 & 12.6 & 48.2 & 14.8 & 12.9 & 13.2 & 5.1 & 6.1 & 1.7 & 2.9 & 9.9 & 66.7 \\
\hline \multicolumn{18}{|l|}{ Region } \\
\hline Norte & 8.5 & 7.5 & 3.3 & 1.3 & 4.4 & 0.0 & 14.1 & 39.3 & 17.1 & 13.5 & 11.5 & 1.2 & 5.4 & 1.4 & 0.8 & 8.4 & 59.2 \\
\hline Capital & 28.0 & 7.5 & 6.8 & 2.2 & 7.8 & 0.2 & 13.2 & 65.8 & 23.1 & 15.2 & 9.8 & 6.8 & 8.6 & 0.3 & 3.3 & 10.9 & 78.1 \\
\hline Golfo & 20.2 & 6.3 & 6.7 & 0.0 & 3.9 & 0.4 & 13.7 & 51.2 & 14.7 & 16.9 & 9.7 & 2.3 & 7.2 & 2.0 & 3.7 & 8.4 & 65.0 \\
\hline Pacifico & 15.9 & 7.1 & 10.7 & 1.9 & 4.0 & 0.0 & 16.9 & 56.6 & 11.0 & 18.7 & 16.2 & 4.0 & 5.1 & 1.0 & 1.1 & 12.2 & 69.4 \\
\hline Sur & 6.5 & 1.5 & 9.1 & 4.5 & 2.4 & 0.4 & 8.6 & 33.0 & 10.6 & 9.9 & 13.2 & 5.0 & 5.3 & 1.9 & 4.7 & 8.8 & 59.5 \\
\hline Centro-Norte & 19.4 & 3.2 & 6.9 & 6.0 & 5.0 & 0.1 & 11.2 & 51.7 & 16.1 & 10.9 & 13.2 & 11.0 & 4.5 & 3.2 & 2.3 & 10.2 & 71.4 \\
\hline Centro & 21.4 & 4.2 & 15.2 & 1.7 & 4.3 & 0.2 & 13.9 & 60.9 & 16.2 & 5.6 & 18.1 & 5.6 & 9.6 & 0.6 & 5.1 & 12.1 & 72.8 \\
\hline
\end{tabular}


The different agricultural income components where not equally hard hit over the decade. The income from cultivation and farm enterprise where most severely affected; the share fell from 30.0 percent to 9.5 percent. The farm and agricultural labor income share dropped from 12.3 to 11.3 percent of total rural income. Also the share of income from self-consumption was reduced; from 8.7 to 3.1 percent during 1992-2002.

Unskilled workers with less than completed primary education receive an average hourly wage income of P\$8.2. This compares to skilled workers with completed high school education who earn $\mathrm{P} \$ 25.0$ or more per hour. Hence, skills are key to obtaining a good job. Hourly wages in rural Mexico increase monotonically with completed levels of education (Figure 2.7). In 2003, a male worker with completed higher education received on average more than 300 percent higher wages than did male workers with no level of completed education. Real wages fell in the 1995-2003 period for the highly skilled. Workers with completed primary, lower and upper secondary, and tertiary education experienced a 3.5, 5.4, 13.1, and 9.9 percent wage reduction, respectively. The average male worker with no completed education experienced the largest hourly wage fall during 1995-2003; 17.2 percent (Figure 2.7).

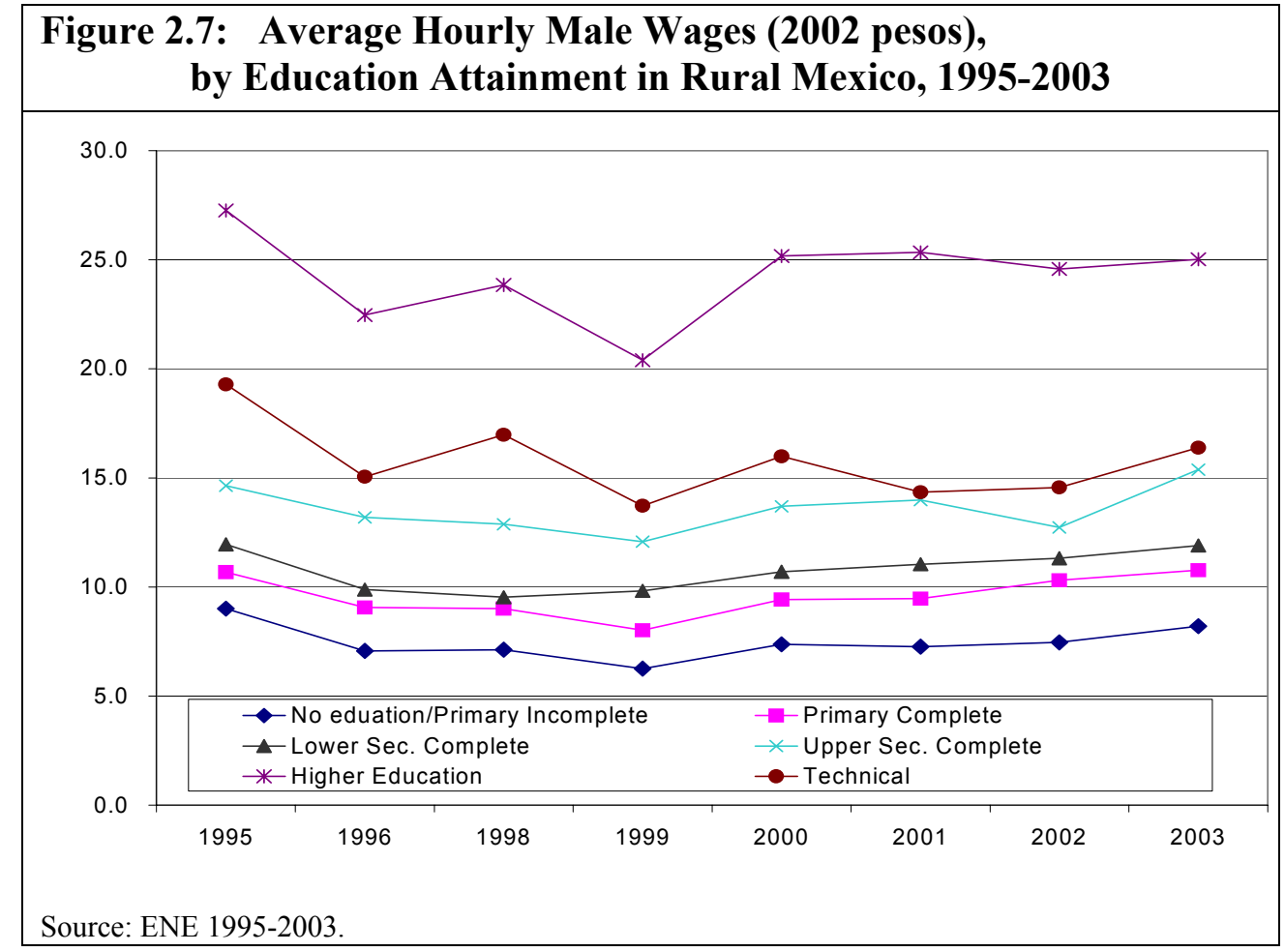

Education is key to poverty reduction. Increased educational attainment can improve the livelihoods of the poor and reduce the likelihood of becoming poor, as shown above. International evidence shows that more education is also a key factor in obtaining a higher income. Furthermore, education is associated with fertility: The more education a woman attains, the lower her fertility rate and, therefore, the lower the dependency ratio and the lower the likelihood of falling into poverty. Therefore, a clear message is that rural Mexicans need to be brought up the educational ladder to escape poverty. Moreover social networks are important (see Araujo, de Janvry and Sadoulet 2003). Both education and social networks will be better addressed in section 3 . 


\section{Rural Income Distribution}

How are incomes from rural nonfarm and farm activities distributed across households along the overall rural expenditure distribution? Figure 2.8 shows income shares by source of income - nonfarm or farm-against quintiles of the per capita consumption distribution for rural Mexico from 1992 to 2002. Across quintiles we observe that farm income is of particular importance to the lower quintiles in the population.

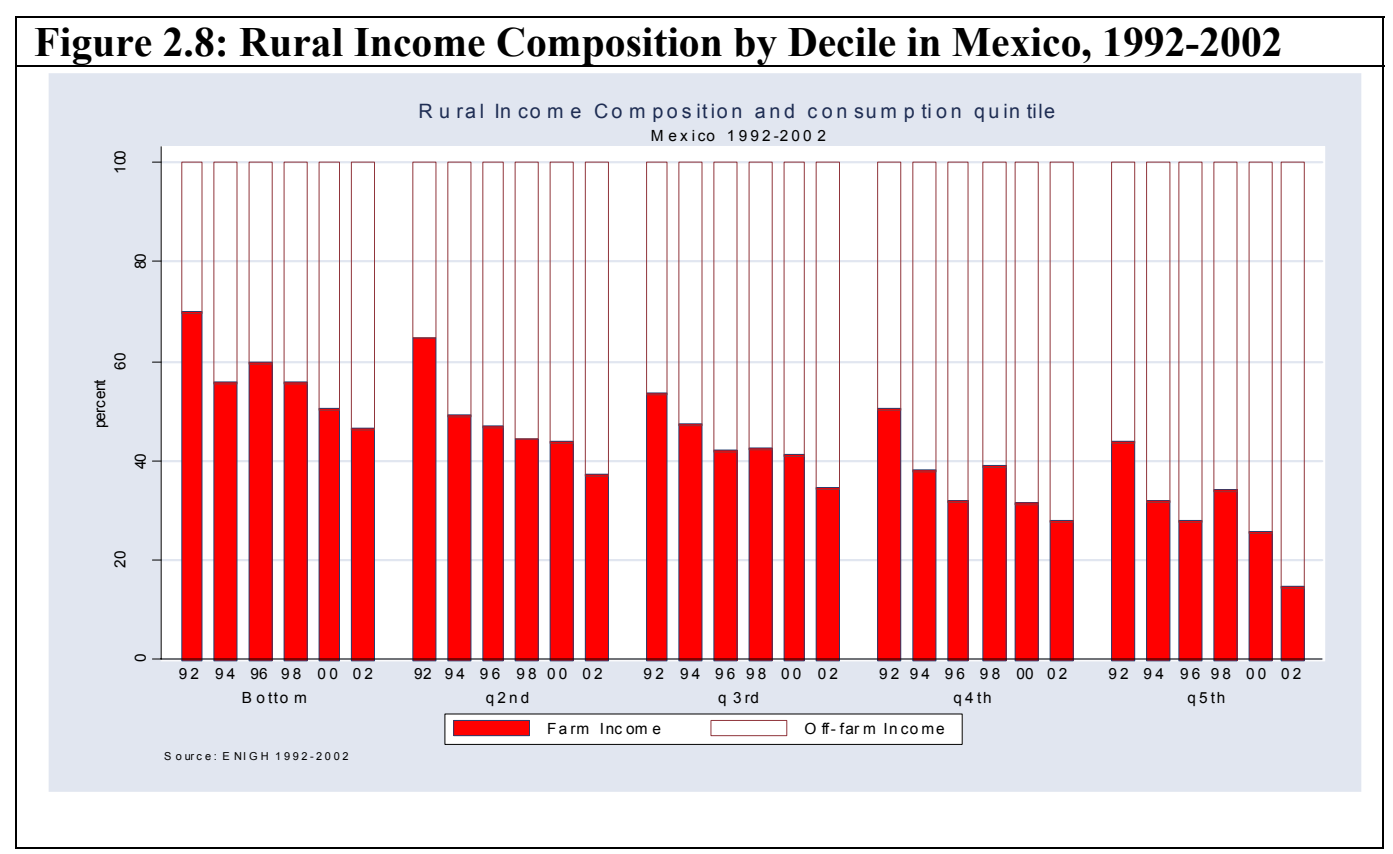

Figure 2.8 shows clearly that the farm income share falls rapidly with time. Moreover, the farm income share also falls as the rural population move up the distribution ladder. The share of farm income of total household income is below 18 percent for the richest 20 percent and above 42 percent for the poorest 20 percent in rural Mexico in 2002. Nonfarm sources of income account for 58 percent for the poorest 20 percent and 80 percent for the richest 20 percent in the consumption distribution in 2002 . During the 1992-2002 period, the share of nonfarm wages increased at a rather constant pace its share of total household income for all quintiles. The nonfarm income increased from around 30 percent in 1992 for the bottom 20 percent of households to over 50 percent in 2002. The top 20 percent experienced an even larger increase in the share from nonfarm activities during 1992-2000.

\section{Wage Determination}

This section looks at determinants of rural wages and investigates whether there is a difference between low and high paid workers by comparing workers located at different places in the wage distribution do this. The wage determination model is 
gauged by ENE survey from 2003 and the quantile regression methodology is applied (see Appendix B for details on the quantile methodology). This methodology characterizes the distribution of wages in more detail than traditional ordinary least squares (OLS) and two stage least squares (2SLS) regressions, as it makes it possible to break down the wage determination process across the entire wage distribution. Additionally, workers are allocated in different groups with different characteristics. Wages are compared across workers organized by gender, education and skills, labor status, and location. Findings for rural areas with more than 15,000 inhabitants are presented in Table 3.1. This section analyzes for each quantile whether the impact of various individual characteristics on wages is homogeneous across the wage distribution. Findings indicate that wages are by no means determined in the same way for high and low paid workers.

\begin{tabular}{|c|c|c|c|c|c|c|c|c|c|c|}
\hline \multirow{4}{*}{\begin{tabular}{|c|} 
Table 3.1: Wage Determinatio \\
\\
Log monthly labor income \\
Worker Characteristics \\
\end{tabular}} & \multirow{2}{*}{\multicolumn{10}{|c|}{ Quantile }} \\
\hline & & & & & & & & & & \\
\hline & \multicolumn{2}{|c|}{0.1} & \multicolumn{2}{|c|}{0.25} & \multicolumn{2}{|c|}{0.5} & \multicolumn{2}{|c|}{0.75} & \multicolumn{2}{|c|}{0.9} \\
\hline & Coeff & SE & Coeff & SE & Coeff & SE & Coeff & SE & Coeff & SE \\
\hline Age & 0.054 & 0.004 & 0.049 & 0.002 & 0.043 & 0.002 & 0.038 & 0.001 & 0.038 & 30.002 \\
\hline Age Square & -0.001 & 0.000 & -0.001 & 0.000 & -0.001 & 0.000 & 0.000 & 0.000 & 0.000 & 0.000 \\
\hline Married woman w/o children & -0.271 & 0.049 & -0.289 & 0.065 & -0.261 & 0.025 & -0.288 & 0.038 & -0.248 & 0.040 \\
\hline Married woman with children & -0.443 & 0.026 & -0.371 & 0.019 & -0.321 & 0.013 & -0.329 & 0.013 & -0.336 & 50.016 \\
\hline Single woman w/o children & -0.317 & 0.030 & -0.303 & 0.016 & -0.330 & 0.009 & -0.351 & 0.011 & -0.330 & 0.013 \\
\hline Single woman with children & -0.255 & 0.031 & -0.252 & 0.022 & -0.280 & 0.016 & -0.327 & 0.014 & -0.350 & 0.017 \\
\hline \multicolumn{11}{|l|}{ Labor Status } \\
\hline Employer & 0.218 & 0.061 & 0.388 & 0.027 & 0.507 & 0.024 & 0.593 & 0.031 & 0.710 & 0.035 \\
\hline Self-employed & -1.516 & 0.052 & -1.163 & 0.028 & -0.623 & 0.014 & -0.278 & 0.016 & -0.118 & 0.026 \\
\hline Informal Salaried & -0.116 & 0.036 & -0.120 & 0.017 & -0.133 & 0.012 & -0.173 & 0.013 & -0.255 & 0.027 \\
\hline Formal Salaried & 0.418 & 0.027 & 0.235 & 0.017 & 0.139 & 0.015 & 0.079 & 0.017 & 0.012 & 20.032 \\
\hline Contract & -0.901 & 0.066 & -0.439 & 0.039 & -0.160 & 0.022 & -0.071 & 0.023 & -0.024 & 40.036 \\
\hline \multicolumn{11}{|l|}{ Education } \\
\hline Primary Complete + & 0.258 & 0.016 & 0.245 & 0.016 & 0.202 & 0.011 & 0.175 & 0.011 & 0.173 & 30.013 \\
\hline Lower Secondary Complete+ & 0.420 & 0.023 & 0.367 & 0.016 & 0.296 & 0.013 & 0.269 & 0.011 & 0.264 & +0.015 \\
\hline Upper Secondary Complete+ & 0.523 & 0.030 & 0.495 & 0.018 & 0.456 & 0.020 & 0.456 & 0.020 & 0.510 & 0.024 \\
\hline University Complete & 0.956 & 0.036 & 0.980 & 0.021 & 0.986 & 0.022 & 0.988 & 0.019 & 1.030 & 0.030 \\
\hline Technical Education & 0.633 & 0.030 & 0.579 & 0.022 & 0.537 & 0.022 & 0.536 & 0.024 & 0.624 & +0.033 \\
\hline \multicolumn{11}{|l|}{ Region $^{3}$} \\
\hline Norte + & 0.376 & 0.035 & 0.376 & 0.019 & 0.376 & 0.019 & 0.253 & 0.012 & 0.274 & +0.026 \\
\hline Capital+ & 0.363 & 0.046 & 0.325 & 0.022 & 0.325 & 0.022 & 0.187 & 0.014 & 0.152 & 20.025 \\
\hline Golfo + & -0.105 & 0.034 & -0.086 & 0.023 & -0.086 & 0.023 & -0.088 & 0.015 & -0.081 & 0.013 \\
\hline Pacifico+ & 0.372 & 0.038 & 0.343 & 0.022 & 0.343 & 0.022 & 0.198 & 0.014 & 0.186 & 50.012 \\
\hline Sur+ & 0.101 & 0.028 & -0.022 & 0.023 & -0.022 & 0.023 & -0.038 & 0.013 & -0.039 & 0.015 \\
\hline Centro-Norte + & 0.215 & 0.037 & 0.202 & 0.025 & 0.202 & 0.025 & 0.104 & 0.012 & 0.093 & 0.014 \\
\hline Locality $<2,500$ inhabitants + & -0.156 & 0.016 & -0.192 & 0.011 & -0.192 & 0.011 & -0.141 & 0.009 & -0.123 & 0.012 \\
\hline Constant & 5.616 & 0.088 & 6.218 & 0.063 & 6.218 & 0.063 & 7.213 & 0.034 & 7.491 & 0.052 \\
\hline
\end{tabular}


Wages are modeled using log monthly wages as the dependent variable. The general wage model contains explanatory variables in levels and allows for nonlinearities in the data. For example, the log wage equation is found to be nonlinear in education and experience. This way of modeling wages indicates that returns to education and experience are not constant but decreasing over the life cycle. In addition, the model contains dummy variables that take the value one if, for example, a worker is a contract worker, and zero otherwise. Such a dummy variable may reveal whether there is a wage premium related to this kind of employment. We use standard quantiles, throughout this section namely the $10^{\text {th }}, 25^{\text {th }}, 50^{\text {th }}, 75^{\text {th }}$, and $90^{\text {th }}$ quantiles.

All included explanatory variables have the expected signs. None of the included variables are not statistically significantly different from zero for all quantiles. Each explanatory variable will now be discussed in turn: (1) education; (2) experience; (3) labor market association; (4) occupation and sector; (5) gender; and (6) rural versus more dispersed rural living and regions.

\section{Education}

Human capital has proven to be important in enhancing long-term economic growth. ${ }^{6}$ A more educated workforce is likely to increase worker productivity, to be flexible and innovative, and to facilitate the adoption and use of new technologies. The increasing speed of technological change faced by firms today and international economic integration means that workers need to have more skills at higher levels in order for firms to be competitive. One reason for this is that more skilled employees can adjust more easily to changes in their firm's economic and technological environment than less skilled workers. ${ }^{7}$ Hence, low returns are an obstacle to economic growth in rural Mexico.

Knowledge about educational wage differentials or wage gaps serves at least three purposes. First, wage differentials reveal the magnitude of incentives or returns obtained by workers acquiring education, and hence, individual educational demand. Second, knowing the extent of economic returns to human capital makes it possible to access whether it is worth making this kind of investment instead of others. Third, wage differentials disclose how the labor market translates educational inequalities into wage inequalities, which is important information in the process of reducing the latter. Furthermore, educational returns link to some extent education to labor productivity and indicate the magnitude of the contribution of education to economic growth. Therefore, it is of interest to estimate the impact of different levels of education and experience on money wages.

${ }^{6}$ See, for example, Barro (1991) and Mankiw, Romer, and Weil (1992).

${ }^{7}$ One issue that needs to be mentioned relates to the endogeneity of education in the regressions. There is vast evidence of a positive correlation between earnings and education. However, social scientists are cautious to draw strong inference about the causal effect of education. In the absence of experimental evidence, it is tricky to recognize whether higher earnings observed for better educated employees are caused by their higher level of completed education, or whether employees with greater earnings capacity have chosen to acquire more education. Card (1998) surveys the literature on the causal relationship between education and earnings and finds that the average marginal returns to education is not much below the estimate that emerges from standard human capital earnings function studies. 
Findings in Table 3.1 confirm the findings of hundreds of other studies, namely that education plays an important role in the wage determination process. Better-educated individuals earn higher wages than their less-educated peers.

Are returns to education constant over the education levels in rural Mexico? According to the findings presented in Table 3.1, the answer is no. ${ }^{8}$ In this analysis, findings allow comparison for workers with no completed level of education (the reference group) or compared with their co-workers who have completed primary school, lower secondary school, higher secondary school, completed tertiary school, and with those who have completed some form of technical education. ${ }^{9}$ In 2003, returns to primary, lower secondary, upper secondary, tertiary, and technical completed education were statistically significantly different from zero and positive for all at the analyzed quantiles, controlling for other individual characteristics in rural Mexico. This finding indicates that having completed at least a few years of education contributes more to wages than not having completed any education at all. Moreover, the premium is rapidly increasing with attained education. In rural Mexico, a median worker experience an impact on wages of 22, 34, 58, and 168 percent for completed primary, lower secondary, upper secondary and tertiary education, respectively. ${ }^{10}$ Moreover, workers with completed technical education received a 71 percent return compared to their peers with no completed education. Better-educated individuals in rural Mexico earn dramatically higher wages than do their less-educated counterparts.

Returns across the wage distribution are fairly constant for workers with completed upper secondary and tertiary education. This indicates that workers in the low end of the income distribution are not being paid less than their peers in the high end (recall from above that very few of the rural population hold a secondary degree). Moreover, this could indicate that: (1) there is no serious problem with heterogeneity of education quality in rural areas, and (2) social capital or networks is quality affective or available for poor and rich workers as there is no difference in returns across the distribution. Hence, poor people seem to benefit to the same degree as richer people from connections, recommendations, etc.

Workers with complete primary and lower tertiary education do face decreasing returns across the wage distribution, i.e. workers in the low end of the income distribution are paid more than their peers in the high end. Hence, workers with the same level of education are not compensated equally. The poor $\left(10^{\text {th }}\right.$ quantile $)$ receive a wage premium when completing primary education and the return generated is 29 percent, while the rich $\left(90^{\text {th }}\right.$ quantile) receive 19 percent. Returns to lower secondary are also little homogeneous. Workers in the low end of the wage distribution $\left(10^{\text {th }}\right.$ quantile $)$ obtain higher returns than workers in the top end $\left(90^{\text {th }}\right.$ quantile), 52 and 30 percent, respectively.

\footnotetext{
${ }^{8}$ Unmeasured ability and measurement error problems have been dealt with in the literature applying data on twins, see for example Card (1998) and Arias, Hollack, and Sosa (1999).

9 The so-called "sheepskin effect" states the existence of wage premiums for completing the final year of elementary school, high school, or university. Therefore, it has been argued that credentials such, as a school diploma or university degree are more important than years of schooling per se. That is one reason for not having a continuous education variable in the regressions.

${ }^{10}$ The percentage return is calculated as (exp(coefficient estimate $\left.)-1\right) * 100$.
} 
One explanation could be that social networks/capital may be working better or be higher among the poorer segments than richer segments of the working population in rural areas.

\section{Experience}

There are several reasons for including experience characteristics in the analysis. One such reason is that a trained and educated workforce provides flexibility in adapting to changes in technology or other economic changes. Experience and years of schooling are widely used in analyses of wage determination (see Mincer 1974, and Levy and Murnane 1992). The measure of experience included in this analysis is general experience measured by the age of the worker.

Are returns to experience homogeneous across the population? According to the findings presented in Table 3.1, the answer is no. The experience variables are statistically significantly different from zero and positive for all five reported quantiles, controlling for other individual characteristics. The impact of experience on wages is positive and increases with age until workers reach 49 years of age. Thereafter, the returns fall at all quantiles. One explanation may be that older workers adapt less easily to new technologies than do younger workers. Returns to experience are falling significantly across the wage distribution in rural Mexico. The variation across quantiles is large; the return to experience is 6 percent in the $10^{\text {th }}$ quantile and 8 percent in the $90^{\text {th }}$ quantile, that is, a 50 percent difference in returns.

\section{Labor market association}

Labor market association is measured by the formality of a worker's job status. That is, whether a worker is engaged in the formal or informal sector. Workers that contribute to the social security system, are allocated to be in the formal sector.

Workers in the informal sector obtain a statistically significant lower pay, controlling for other variables (Table 3.1). The negative impact on wages of work in the informal sector is increasing across the wage distribution; a worker placed in the $10^{\text {th }}$ quantile obtains a wage low-grade or deduction of 11 percent whereas a worker in the $75^{\text {th }}$ quantile and above receives a 17 percent or more low-grade. The informal sector generally supplies lower quality jobs than the formal sector. Since higher quality jobs may require more skills, the informal sector variable may capture skill differences, which the other included variables do not capture. The wage gap may also be caused by lower productivity in the informal sector relative to the formal sector or other, which is not captured by human capital. Hence, workers in the informal sector are disadvantaged in at least two ways: first, they do not have access to social security or alike; and second, they obtain lower wages, which evidently does not compensate informal workers for the absence of social security. Informal sector workers are not only disfavored in terms of wages and social security, but they may also work in an environment where they are more exposed to the risk for accidents occurring, etc.. 


\section{Labor status}

The labor status of workers is also included in the determination of wages. All the included occupational groups are statistically significant and different from zero and positive (except contract workers and formal salaried workers in the $90^{\text {th }}$ quantile). Analyzing at the median, employers obtain the highest return of 66 percent, that is, 51 and 89 percent more than the formal workers and informal workers, respectively, controlling for other factors such as level of human capital. For the $90^{\text {th }}$ quantile, the premium- gap is even larger; 103 and 126 percent, respectively. Hence, regarding labor status there exist substantial differences across the wage distribution.

\section{Gender}

Discrimination at an individual level is said to arise if an otherwise identical person is treated differently by virtue of that person's ethnicity or gender, and ethnicity or gender by themselves have no direct effect on productivity. Under perfect competition in the capital and labor markets, equivalent employees in equivalent jobs are compensated equally, that is, there is no discrimination.

The estimation of discrimination is difficult. Worker productivity is seldom observed directly, so data must be used to proxy for the relevant productivity characteristics. The main debate occurs over whether relevant omitted characteristics differ between ethnicity, and between gender, and whether certain included characteristics capture productivity differences or instead are a proxy for ethnicity or gender. The following section reports findings on gender differences, and due to lack of data in ENE on ethnic origin, no findings are reported on ethnicity. The analysis includes four gender variables: married women without and with children and single women with and without children.

Are returns to gender homogeneous across the population living in rural Mexico? The regression findings show signs of large measurable inequalities between men and women. Female wages are statistically significantly different from male wages at all quantiles. Moreover, findings also suggest that the gender gap is homogeneous across the quantiles for women without children (both married and single), but heterogeneous across the quantiles for women with children (both married and single). Single women with children experience the largest wage-gap at the low end of the distribution; they obtain 23 percent lower wages than their male peers in the $10^{\text {th }}$ quantile. The gap narrows along the distribution and reaches 30 percent at the $90^{\text {th }}$ quantile.

The gender-earning gap may, to some degree, be explained by jobs chosen by women. Women are more likely than men to select jobs, which are more flexible in nature. For example, women may choose part time jobs or jobs with lower working hours than men (on average Mexican female workers work 24 percent less hours than their male peers, see Table 2.3). A second factor may be gender differences in unmeasured skills. Education levels are taken into account, but some women's skill levels may be lower than men's. Hence, data reveal that some women are under capitalized in terms of education, as they have less completed education than males (for example a smaller share of women have primary complete than males, see Table 3.3), but they may very well be under capitalized too in terms of experience. Additionally, many women 
choose professions where they are less forced to capitalize, for example, they work more often in teaching than male peers. Hence, direct discrimination is less strong than it appears according to findings presented in Table 3.1.

\section{Dispersed Rural Living}

This subsection analyzes wage premia related to more dispersed rural living (areas with less than 2,500 inhabitants); the variable quantifies the wage effect of living in semiurban versus more dispersed rural areas.

Urban or semi-urban areas exist because it is an advantage to pursue production and consumption activities in a spatial concentrated fashion. This combined with the high population density, drives up prices of, for example, land. To compensate for higher prices, workers in urban and semi-urban areas require recompense. Findings show that in Mexico, workers do receive compensation (Table 3.1). Workers in dispersed rural areas are paid statistically significantly less than workers in semi-urban rural areas, when controlling for other characteristics. The semi-urban - dispersed rural wage gap is significantly different from zero for all quantiles and varies across the wage distribution. It increases from the $10^{\text {th }}$ to the $50^{\text {th }}$ quantile and declines from the $50^{\text {th }}$ to the $90^{\text {th }}$ quantiles, controlling for other covariates. The semi-urban premium is 12 percent for the median worker.

\section{Correlates of Nonagriculture}

What determines who is most likely to seek employment outside the agricultural sector? Section 2 clearly showed that nonagricultural activities are expanding and most income is generated in this sector. This section examines factors, which are associated with employment in nonagricultural activities in rural localities with less than 15,000 inhabitants.

The analyses of participation in nonfarm activities are multivariate and contain an estimation of a probit model of involvement in nonfarm activities as a primary occupation on a range of individual, household, and geographical characteristics. The specification of the model draws on findings from Section 3, which suggests that the choice of primary occupation is affected by geographical location and education, as well as gender and age among other variables. Rather than reporting the parameter estimates, which are difficult to interpret on their own, Table 4.1 presents the marginal effects associated with each explanatory variable. These can be interpreted as indicating the effect of a percentage change in the explanatory variable on the probability of involvement in nonfarm business activities, taking all other variables in the specification at their means. ${ }^{11}$

\footnotetext{
${ }^{11}$ For dummy variables, the marginal effect is calculated as the change in the dependent variable associated with a move from a value of zero for the dummy, to one, holding all other variables constant at mean values.
} 
Findings from Section 2 and recent research have shown that the nonfarm sector can often be seen as a source of both high-return employment as well as a "last resort" option (see Ferreira and Lanjouw 2001). Therefore, as Ferreira and Lanjouw, this paper also presents estimations of two additional models with the same specification of regressor, but differentiating between high-return nonfarm activities as opposed to lowreturn nonfarm activities. The nonfarm subsectors are designated as either high-return or low-return depending on the average monthly earnings accruing to the individuals whose primary occupation is in that sector. If the average monthly wage is below the average wage, the subsector is designated as low return, or low productivity, sector. Conversely, if the average monthly return from a subsector is above the average wage, the subsector is designated as high return.

Table 4.1 presents three probit models linking the probability of having primary employment in nonagricultural wage-labor occupation to a range of explanatory variables. Included in the analyses are household size, age, age squared, gender, schooling, locations with less than 2,500 people, and regional dummies. In the first model, comprising all nonfarm activities in rural Mexico combined, the dependent variable takes the value of 1 if the person is primarily employed in nonagricultural wage labor and zero otherwise. The second and third model split those employed in the nonagricultural labor force into two groups; those with a low productivity (low-return) job and those with a high productivity (high-return) job.

Considering all nonfarm employment together, women are significantly more heavily represented in the nonagricultural wage-labor force than men, controlling for all other variables (Table 4.1). This finding is different from other countries, for example, the poor Northeast Brazil where women are more likely to be represented in the agricultural sector (see Ferreira and Lanjouw 2001).

After dividing the types of occupation into two groups depending on whether earnings are lower or higher than the average wage, women are significantly more likely than men to be employed in low-return nonagricultural activities, but not for high-return nonagricultural activities. These findings do not seem to change with the marital status and family structure, that is, whether the woman is married or not and whether she has children or not. These findings may not be very robust, however, since the ENE sampling is done in the second quarter where harvests are few.

The probability of nonfarm employment rises with age, controlling for other characteristics. Age is an important factor explaining the probability of being employed in nonagricultural sectors. Age is positively associated with nonagricultural employment in general, and the impact is even larger for high-productivity employment. Moreover, age is nondeclining at a certain age in rural Mexico. This finding contrasts findings from Brazil where the older workers have a smaller probability of being employed off-farm (Ferreira and Lanjouw 2001). The average age also increased for the rural active population (see Section 2) as many younger people have migrated, there is fewer younger workers left. 


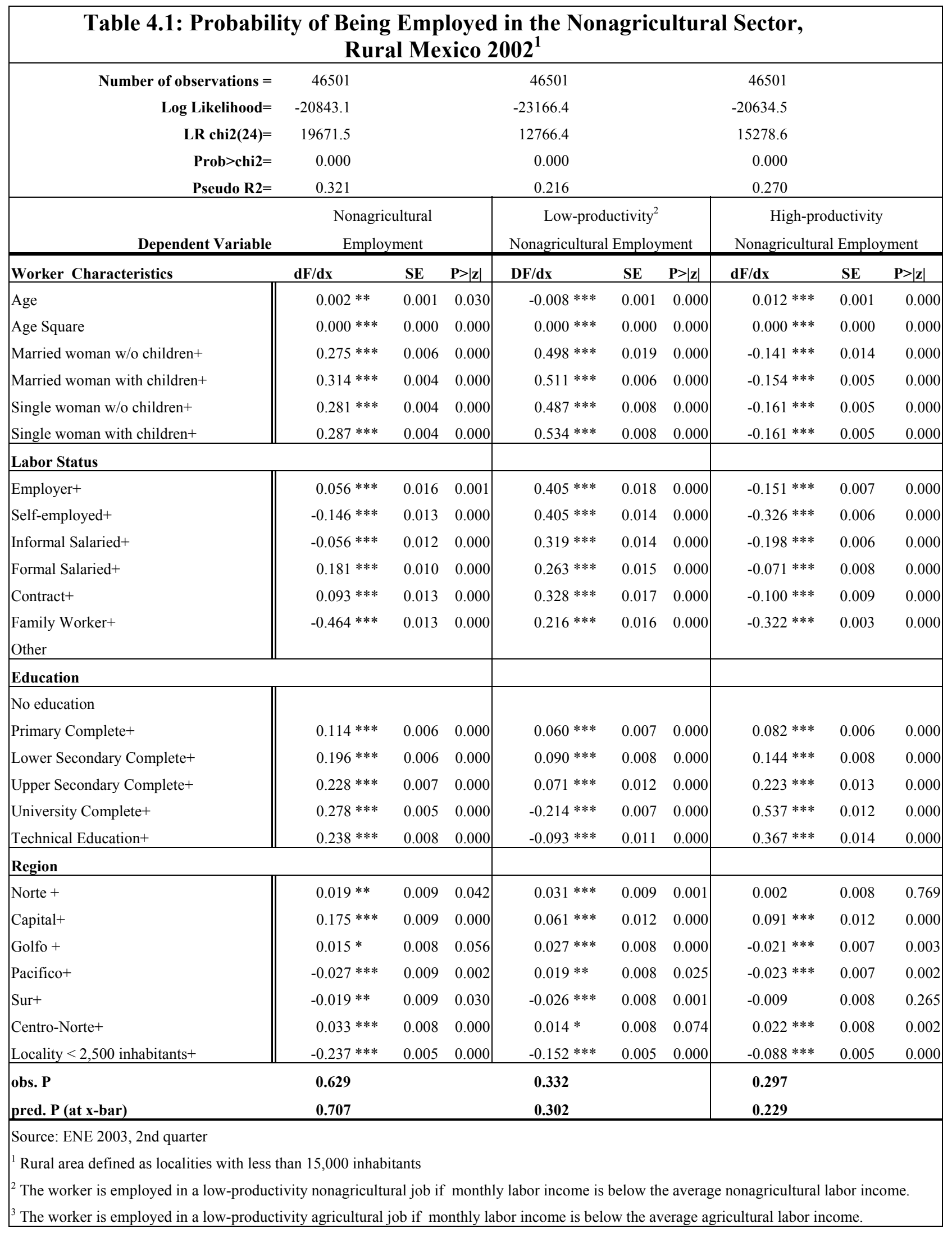


The effect of education is strong as has been found in other studies. For example Taylor and Yuwez-Naude (2000) find evidence of high returns from schooling in both crop and noncrop activities in Mexico (see also Ferreira and Lanjouw 2001 for a review). Findings in Table 4.1 show that the probability of involvement in the nonfarm sector is positively and significantly related to education levels in rural Mexico. Relative to the uneducated, those with education are generally more likely to find employment in the nonagricultural sector, controlling for other variables. Findings in Table 4.1 reveal that as education attainment rises, so does the probability of being employed in the nonagricultural sector. What may, at first, seem striking, is that after dividing the types of occupation into two groups, workers with completed university education are not more likely to be employed in the relatively low productivity occupations. In the high productivity jobs, completed primary and lower and upper secondary education dummies are all statistically significant. Average values of other variables, having completed primary education raises the probability of employment in high-return jobs to 8 percent. Raising one's education to the secondary level shows that high school educated are more than double as likely to be employed in the high-return nonagricultural employment than primary educated workers. Moreover, university graduates have a much larger probability of working in high return nonfarm jobs than do secondary school graduates. It is important to acknowledge that the exogeneity of education in these models can be questioned so more research would be needed to understand employment possibilities in high-productive sectors.

Moreover spatial heterogeneity is large within states and regions and there seems to be a strong locality connection in rural Mexico. Location influences probabilities of nonfarm sector participation; even after controlling for other characteristics. Workers living in localities smaller than 2,500 inhabitants are less likely to be employed in highproductive nonagricultural sectors and nonagricultural sectors generally. The regression model for low-productive nonagricultural sectors reveals that workers in small localities are even statistically more likely to be employed in this sector. This indicates that workers in dispersed rural localities with few inhabitants are not stuck with cultivation only as wage employment opportunities exist. Improving transport infrastructure that provides access to more inhabited rural or urban centers may translate into better access to off-farm jobs. Araujo (2003) finds that interventions in roads are more effective in reducing poverty, through nonfarm rural employment in rural municipalities with low value agriculture outputs, but high productivity of labor.

Relative to those living in the Center region, workers in the North region are more likely to be employed in low-return nonfarm activities and equally likely to be employed in high-return jobs, controlling for individual characteristics. The South region's rural population are less likely than those in the Center region to be employed in nonagricultural activities and, especially so in low-productivity ones.

Access to land may also be an important factor to determine sector of labor market participation. In fact Finan, Sodoulet and de Janvry (2002) find that young educated men from land-poor households in Mexico are more likely to participate in offfarm nonagricultural employment. Our data unfortunately do not allow including access to land as an explanatory factor in the analysis. 


\section{Conclusion}

Rural poverty remains a crucial part of the poverty story in Mexico as a whole. Mexico is a fairly largely urbanized country, but poverty in rural areas is so widespread and persistent that about 13 million poor are still found in the countryside (Verner 2004). Therefore, it seems clear that the rural economy must remain a central focal point for policy makers aiming to reduce poverty given the level and growth of the rural nonagricultural sector in Mexico. It is natural that attention is increasingly focused on the role that these occupations play in improving living conditions and reducing poverty and social exclusion.

This distribution profile of the sector revealed that nonfarm income shares increase with overall consumption levels and, also, with time. The rural population in lower quintiles of the consumption distribution tends to earn a larger share of their nonagricultural incomes from wage labor activities. For the poorest, lowreturn/productivity wage labor activities are important.

The quantile wage regression analysis for rural Mexico shows a rather heterogeneous impact pattern of individual characteristics across the wage distribution on monthly wages. That is, the magnitude of the affect of a wage determinant is different depending on the worker being rich, poor or placed in the median of the wage distribution. Findings reveal that education is key to earning higher wages; the more educated workers earn higher wages than their less educated peers. Also experience impacts positively on wages and it is increasing with age. Gender disparities are also at play in the rural Mexican labor market. Finally, workers in more dispersed rural areas earn less than their peers in semi-urban rural areas (localities with less than 15,000 inhabitants).

The rural nonfarm sector is heterogeneous and includes a great variety of activities and productivity levels across nonfarm jobs. Moreover it can reduce poverty in a couple of distinct but qualitatively important ways in rural Mexico. First, highproductivity activities seem to provide the rural population with sufficient income to escape poverty. Second, vulnerable segments of the population, such as women and many of the poorest tend to be concentrated in the low or less productive rural nonagricultural activities - mainly due to skill and educational deficiencies and location disadvantages. These low-productivity/return occupations nevertheless provide a critical contribution to their livelihoods preventing further destitution.

When examining correlates of nonfarm employment in rural Mexico, findings suggest that the two key determinants of access to employment and productivity in nonfarm activities are education and location. Both determinants are also significantly correlated with poverty (Verner 2005). First, there is strong evidence that the educated have better prospects in the nonfarm sector. This is emphasized when nonfarm activities are divided into low-return and high-return activities. Education is a particularly important determinant of employment in the better-paid nonfarm activities. Second, the nonagricultural sector is also closely linked to location. There appears to be evidence that the nonfarm sectors are more vibrant in more populated areas which are connected to 
markets and enjoy certain minimum standards of infrastructure. Hence it is key that governments assist in augmenting the human capital of the rural population in more dispersed rural areas so they can move and take advantage of increased job opportunities. 


\section{References}

Araujo, C., A.de Janvry and E. Sadoulet (2003). "Measuring the role of social networks on behavior with an application to rural off-farm employment", Department of Agricultural and Resource Economics University of California Berkeley. Mimeo.

Arias, O., K.F. Hollack, and W. Sosa (1999). "Individual Heterogeneity in the Returns to Schooling: Instrumental Variables Quantile Regression Using Twins Data,” Mimeo, University of Illinois.

Barro, R.J. (1991). "Economic Growth in a Cross Section of Countries", Quarterly Journal of Economics, Vol. 106, No. 2.

Buchinsky, M. (1998). "Recent Advances in Quantile Regression Models - A Practical Guideline for Empirical Research", The Journal of Human Resources, Vol. XXXIII, No. 1, pp. 88-126.

Card, D. (1998). "The Causal Effect of Education on Earnings", forthcoming in Handbook of Labor Economics, Vol. 3, Ashenfelter, O. and Card, D. (eds.).

Deaton, A. (1997). "The Analysis of household Surveys - A Microeconometric Approach to Development Policy", Johns Hopkins University Press, Baltimore.

Finan, F., E. Sadoulet, and A.de Janvry (2002). "Measuring the Poverty Reduction Potential of Land in Rural Mexico", University of California at Berkeley. Mimio.

Ferreira, F. and P. Lanjouw (2001). "Rural Poverty and Nonfarm Employment in Brazil", World Development, 29/3, 509-528.

Juhn, C., K.M. Murphy, and Pierce, B. (1993). "Wage Inequality and the Rise in Returns to Skills", Journal of Political Economy, Vol. 101, No. 3.

Koenker, R. and Basset, G. Jr. (1978). "Regression Quantiles”, Econometrica, Vol. 46, No. 1, pp. 33-50.

Koenker, R. and D’Orey (1993). "Computing Regression Quantiles", Applied Statistics, 36, pp. 383-393, and 43, pp. 410-414.

Koenker, R. and Portnoy (1997) "Quantile Regression”, Office of Research Working Paper, No. 97-0100, College of Commerce and Business Administration, University of Illinois at Urbana-Champaign.

Lanjouw, J. O. and P. Lanjouw (2001). "The Rural NonFarm Sector: Issues And Evidence From Developing Countries", Agricultural Economics 24, p.1-23.

Levy, F. and R. J. Murnane (1992). "U.S. Earnings Levels and Earnings Inequality: A Review of Recent Trends and Proposed Explanations", Journal of Economic Literature, Vol. 30, pp. 1333-1381. 
Maloney, W. F. and Ribeiro, E.P. (1999). "Efficiency Wage and Union Effects in Labor Demand and Wage Structure in Mexico: An Application of Quantile Analysis", Working Paper, The World Bank.

Mankiw, N.G., Romer, D., and Weil, D.N. (1992). "A Contribution to the Empirics of Economic Growth", Quarterly Journal of Economics, Vol. 107, No. 2.

Mincer, J. (1974). "Schooling, Experience and Earnings", NBER Working Paper, New York.

Taylor, J. E. and A. Yuwez-Naude (2000). "The Returns From Schooling In A Diversified Rural Economy", American Journal of Agriculture Econ. 82, May: 287297.

Verner, D. (2004). "Rural Poverty in Mexico During 1992-2002", The World Bank, Washington, DC. Mimio. 


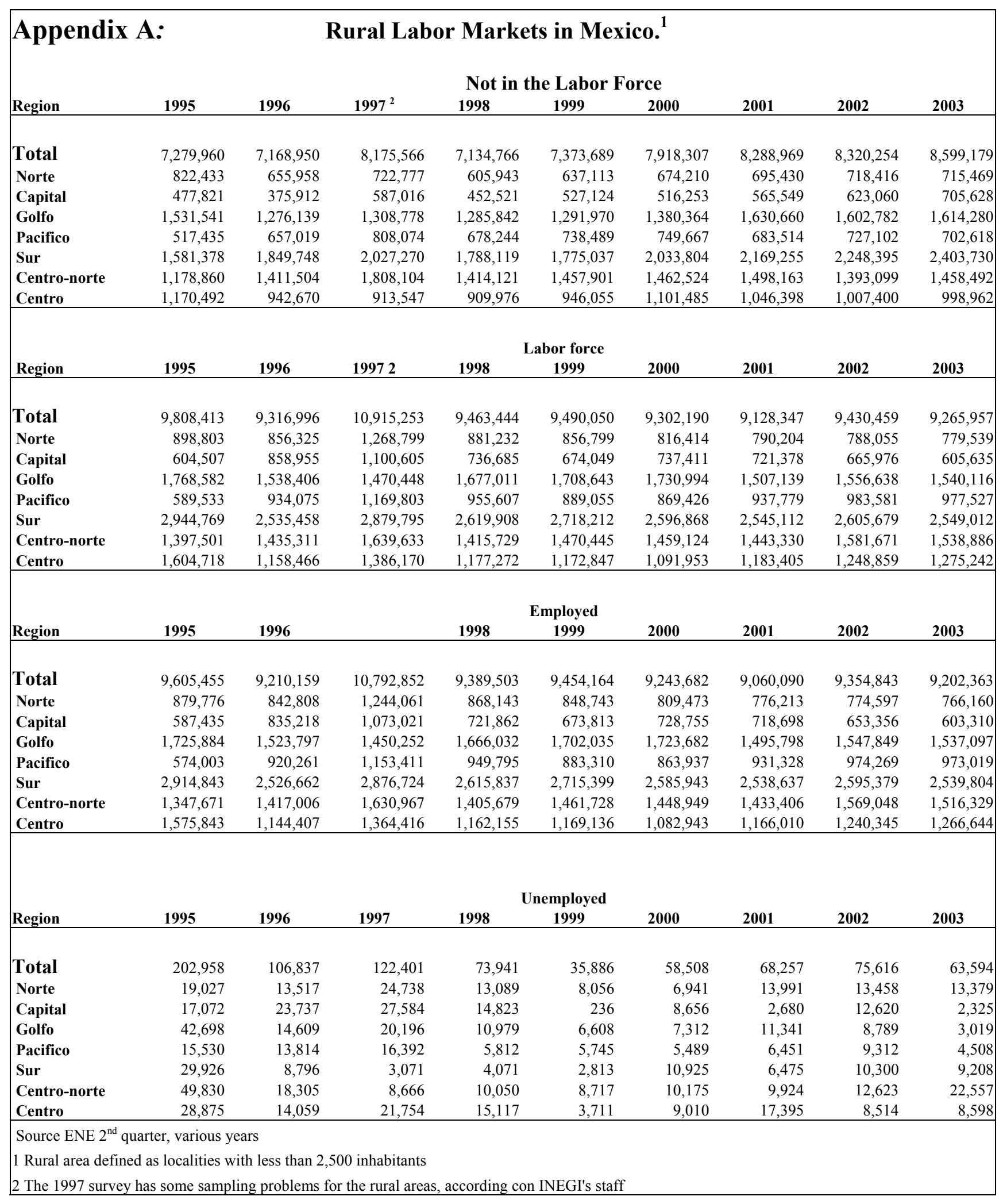




\section{Appendix B. Quantile Regressions}

\section{Economic model}

The underlying economic model used in the analysis will simply follow Mincer's (1974) human capital earnings function extended to control for a number of other variables that relate to location. In particular, we apply a semi-logarithmic framework that has the form:

$\ln y_{i}=\varphi\left(x_{i}, z_{i}\right)+u_{i}$

where $\ln \mathrm{y}_{\mathrm{i}}$ is the $\log$ of earnings or wages for an individual, $\mathrm{I}$; $\mathrm{x}_{\mathrm{i}}$ is a measure of a number of personal characteristics including human capital variables, ethnicity, etc.; and $\mathrm{Z}_{\mathrm{i}}$ represents location specific variables - for instance, metropolitan living. The functional form is left unspecified in equation (1). The empirical work makes extensive use of dummy variables in order to catch nonlinearities in returns to years of schooling, tenure, and other quantitative variables. The last component, $\mathrm{u}_{\mathrm{i}}$, is a random disturbance term that captures unobserved characteristics.

\section{Quantile regressions}

Labor market studies usually make use of conditional mean regression estimators, such as Ordinary Least Squares. This technique is subject to criticism because of several, usually, heroic assumptions underlying the approach. One is the assumption of homoskedasticity in the distribution of the error terms. If the sample is not completely homogenous, this approach, by forcing the parameters to be the same across the entire distribution of individuals, may be too restrictive and may hide important information.

The method applied in this paper is quantile regression. The idea is that one can choose any quantile and thus obtain many different parameter estimates on the same variable. In this manner the entire conditional distribution can be explored. By testing whether coefficients for a given variable across different quantiles are significantly different, one implicitly also tests for conditional heteroskedasticity across the wage distribution. This is in particular interesting for developing countries such as Mexico where wage disparities are huge and returns to, for example, human capital may vary across the distribution.

The method has many other virtues apart from being robust to heteroskedasticity. When the error term is nonnormal, for instance, quantile regression estimators may be more efficient than least squares estimators. Furthermore, since the quantile regression objective function is a weighted sum of absolute deviations, one obtains a robust measure of location, and as a consequence the estimated coefficient vector is not sensitive to outlier observations on the dependent variable. ${ }^{12}$

12 That is, if $y_{i}-x_{i}^{\prime} \hat{\beta}_{\theta}>0$, then $\mathrm{y}_{\mathrm{i}}$ can be increased towards $+\infty$, or if $y_{i}-x_{i}^{\prime} \hat{\beta}_{\theta}<0$, $\mathrm{y}_{\mathrm{i}}$ can be decreased towards $-\infty$, without altering the solution $\hat{\beta}_{\theta}$. In other words, it is not the magnitude of the dependent variable that matters, but on which side of the estimated hyperplane the observation is. This 
The main advantage of quantile regressions is the semi-parametric nature of the approach, which relaxes the restrictions on the parameters to be fixed across the entire distribution. Intuitively, quantile regression estimates convey information on wage differentials arising from nonobservable characteristics among individuals otherwise observationally equivalent. In other words, by using quantile regressions, we can determine if individuals that rank in different positions in the conditional distribution (i.e., individuals that have higher or lower wages than predicted by observable characteristics) receive different premiums to education, tenure, or to other relevant observable variables.

Formally the method, first developed by Koenker and Basset (1978), can be formulated as ${ }^{13}$

$\mathrm{y}_{\mathrm{i}}=\mathrm{x}_{\mathrm{i}}^{\prime} \beta_{\theta}+\mathrm{u}_{\theta \mathrm{i}}=\operatorname{Quant}_{\theta}\left(\mathrm{y}_{\mathrm{i}} \mid \mathrm{x}_{\mathrm{i}}\right)=\mathrm{x}_{\mathrm{i}}^{\prime} \beta_{\theta}$

where Quant ${ }_{\theta}\left(\mathrm{y}_{\mathrm{i}} \mid \mathrm{x}_{\mathrm{i}}\right)$ denotes the $\theta^{\text {th }}$ conditional quantile of $\mathrm{y}$ given $\mathrm{x}$, and $i$ denotes an index over all individuals, $i=1, \ldots, \mathrm{n}$.

In general, the $\theta^{\text {th }}$ sample quantile $(0<\theta<1)$ of $y$ solves

$$
\min _{\beta}=\frac{1}{n}\left\{\sum_{i: y_{i} \geq x_{i}^{\prime} \beta} \theta\left|y_{i}-x_{i}^{\prime} \beta\right|+\sum_{i: y_{i}<x_{i}^{\prime} \beta}(1-\theta)\left|y_{i}-x_{i}^{\prime} \beta\right|\right\}
$$

Buchinsky (1998) examines various estimators for the asymptotic covariance matrix and concludes that the design matrix bootstrap performs the best. In this paper, the standard errors are obtained by bootstrapping using 200 repetitions. This is in line with the literature.

is most easily seen by considering the first-order-condition, which can be shown to be given as (see Buchinsky 1998) $\frac{1}{n} \sum_{i=1}^{n}\left(\theta-\frac{1}{2}+\frac{1}{2} \operatorname{sgn}\left(y_{i}-x_{i}^{\prime} \hat{\beta}_{\theta}\right)\right) x_{i}=0$.

This can be seen both as a strength and weakness of the method. To the extent that a given outlier represents a feature of "the true" distribution of the population, one would prefer the estimator to be sensitive to such an outlier - at least to a certain degree.

${ }^{13}$ See Buchinsky (1998). 


\begin{tabular}{|c|c|c|c|c|c|c|c|c|c|c|c|c|c|c|}
\hline \multicolumn{15}{|c|}{ Appendix B: Income shares by source and (consumption) Quintile, rural Mexico (Localities with less than 2,500 inhabitants), 2002} \\
\hline & \multicolumn{3}{|c|}{ Agriculture } & \multirow[b]{2}{*}{$\begin{array}{c}\text { Total } \\
\text { Agriculture }\end{array}$} & \multicolumn{9}{|c|}{ Nonagricultural income sources } & \multirow[b]{2}{*}{$\begin{array}{c}\text { Total } \\
\text { Nonagricultural }\end{array}$} \\
\hline & $\begin{array}{l}\text { Agricultural } \\
\text { Enterprise }\end{array}$ & $\begin{array}{c}\text { Self - } \\
\text { Consumption }\end{array}$ & $\begin{array}{l}\text { Agricultural } \\
\text { Labor }\end{array}$ & & $\begin{array}{l}\text { Low-return } \\
\text { Nonfarm } \\
\text { Labor }\end{array}$ & $\begin{array}{l}\text { High-return } \\
\text { Nonfarm } \\
\text { Labor }\end{array}$ & $\begin{array}{l}\text { Nonfarm } \\
\text { Enterprise }\end{array}$ & $\begin{array}{l}\text { Remittances } \\
\text { Income }\end{array}$ & $\begin{array}{l}\text { Other } \\
\text { Private } \\
\text { Transfer }\end{array}$ & $\begin{array}{l}\text { PROGRESA } \\
\text { Income }\end{array}$ & $\begin{array}{l}\text { PROCAMPO } \\
\text { Income }\end{array}$ & $\begin{array}{c}\text { Other } \\
\text { Public } \\
\text { Transfer }\end{array}$ & \multirow{2}{*}{$\begin{array}{l}\text { Other } \\
\text { Income } \\
(\%)\end{array}$} & \\
\hline & $\begin{array}{c}\text { Income } \\
(\%)\end{array}$ & $(\%)$ & $\begin{array}{c}\text { Income } \\
(\%)\end{array}$ & $\begin{array}{c}\text { Income } \\
(\%)\end{array}$ & $\begin{array}{c}\text { Income }^{\mathrm{e}} \\
(\%)\end{array}$ & $\begin{array}{l}\text { Income } \\
(\%)\end{array}$ & $\begin{array}{c}\text { Income } \\
(\%)\end{array}$ & $(\%)$ & $\begin{array}{c}\text { Income } \\
(\%)\end{array}$ & $(\%)$ & $(\%)$ & $\begin{array}{c}\text { Income } \\
(\%)\end{array}$ & & $\begin{array}{c}\text { Income } \\
(\%)\end{array}$ \\
\hline TOTAL & 9.5 & 3.1 & 11.3 & 23.8 & 12.3 & 23.8 & 5.7 & 5.9 & 4.4 & 3.2 & 2.8 & 0.2 & 17.8 & 76.2 \\
\hline \multicolumn{15}{|c|}{ Rural per capita consumption quintile } \\
\hline Bottom & 12.4 & 6.1 & 28.1 & 46.6 & 11.5 & 2.8 & 4.3 & 1.7 & 5.1 & 12.0 & 4.7 & 0.3 & 10.9 & 53.4 \\
\hline 2nd & 10.0 & 4.7 & 22.3 & 37.1 & 14.4 & 8.3 & 6.0 & 4.5 & 5.0 & 8.5 & 3.6 & 0.7 & 11.9 & 62.9 \\
\hline 3rd & 10.4 & 3.6 & 20.5 & 34.6 & 16.8 & 11.1 & 7.6 & 4.7 & 4.7 & 5.7 & 2.9 & 0.4 & 11.5 & 65.4 \\
\hline 4th & 9.9 & 2.8 & 15.3 & 28.0 & 19.0 & 14.1 & 6.7 & 8.0 & 4.7 & 3.1 & 2.5 & 0.2 & 13.5 & 72.0 \\
\hline 5th & 8.6 & 2.4 & 3.8 & 14.8 & 8.6 & 35.4 & 5.0 & 6.2 & 4.0 & 0.6 & 2.5 & 0.1 & 22.7 & 85.2 \\
\hline \multicolumn{15}{|c|}{ Poor/non poor (food poverty line) } \\
\hline Nonpoor & 9.2 & 2.6 & 9.6 & 21.4 & 12.2 & 27.0 & 5.5 & 6.2 & 4.2 & 1.7 & 2.6 & 0.2 & 18.8 & 78.6 \\
\hline Poor & 10.9 & 5.9 & 21.9 & 38.7 & 12.8 & 4.4 & 6.8 & 3.8 & 5.5 & 11.9 & 3.8 & 0.4 & 11.9 & 61.3 \\
\hline \multicolumn{15}{|c|}{ Poor/non poor (assets poverty line) } \\
\hline \multirow{3}{*}{ Poor } & \multicolumn{3}{|c|}{ Agriculture } & \multicolumn{10}{|c|}{ Nonagricultural income sources } & \\
\hline & $\begin{array}{l}\text { Agricultural } \\
\text { Enterprise }\end{array}$ & $\begin{array}{c}\text { Self - } \\
\text { Consumption }\end{array}$ & $\begin{array}{l}\text { Agricultural } \\
\text { Labor }\end{array}$ & $\begin{array}{c}\text { Total } \\
\text { Agriculture }\end{array}$ & $\begin{array}{l}\text { Low-return } \\
\text { Nonfarm } \\
\text { Labor }\end{array}$ & $\begin{array}{l}\text { High-return } \\
\text { Nonfarm } \\
\text { Labor }\end{array}$ & $\begin{array}{l}\text { Nonfarm } \\
\text { Enterprise }\end{array}$ & $\begin{array}{l}\text { Remittances } \\
\text { Income }\end{array}$ & $\begin{array}{l}\text { Other } \\
\text { Private } \\
\text { Transfer }\end{array}$ & $\begin{array}{l}\text { PROGRESA } \\
\text { Income }\end{array}$ & $\begin{array}{l}\text { PROCAMPO } \\
\text { Income }\end{array}$ & $\begin{array}{c}\text { Other } \\
\text { Public } \\
\text { Transfer }\end{array}$ & $\begin{array}{l}\text { Other } \\
\text { Income }\end{array}$ & $\begin{array}{c}\text { Total } \\
\text { Nonagricultural }\end{array}$ \\
\hline & $\begin{array}{l}\text { Income } \\
(\%)\end{array}$ & $(\%)$ & $\begin{array}{c}\text { Income } \\
(\%)\end{array}$ & $\begin{array}{c}\text { Income } \\
(\%)\end{array}$ & $\begin{array}{c}\text { Income }^{\mathrm{e}} \\
(\%)\end{array}$ & $\begin{array}{c}\text { Income } \\
(\%)\end{array}$ & $\begin{array}{c}\text { Income } \\
(\%)\end{array}$ & $(\%)$ & $\begin{array}{c}\text { Income } \\
(\%)\end{array}$ & $(\%)$ & $(\%)$ & $\begin{array}{c}\text { Income } \\
(\%)\end{array}$ & $(\%)$ & $\begin{array}{c}\text { Income } \\
(\%)\end{array}$ \\
\hline TOTAL & 6.5 & 2.5 & 8.2 & 17.1 & 12.5 & 27.5 & 8.6 & 4.4 & 6.1 & 2.2 & 1.8 & 1.1 & 18.8 & 82.9 \\
\hline \multicolumn{15}{|c|}{ Rural per capita consumption quintile } \\
\hline Bottom & 12.2 & 5.5 & 26.3 & 44.0 & 10.9 & 5.7 & 5.6 & 2.1 & 5.6 & 11.0 & 3.9 & 0.3 & 10.9 & 56.0 \\
\hline 2nd & 9.0 & 3.5 & 19.8 & 32.3 & 18.9 & 11.5 & 6.5 & 4.5 & 5.3 & 6.4 & 2.6 & 0.6 & 11.4 & 67.7 \\
\hline $3 \mathrm{rd}$ & 6.4 & 2.5 & 13.4 & 22.3 & 19.0 & 15.4 & 15.5 & 4.5 & 4.5 & 3.6 & 2.0 & 0.3 & 12.8 & 77.7 \\
\hline 4 th & 7.9 & 2.3 & 9.2 & 19.4 & 18.4 & 22.5 & 10.4 & 5.8 & 5.2 & 2.0 & 1.4 & 0.3 & 14.6 & 80.6 \\
\hline 5 th & 4.9 & 2.0 & 2.2 & 9.1 & 7.6 & 37.8 & 6.8 & 4.2 & 7.0 & 0.2 & 1.4 & 1.7 & 24.1 & 90.9 \\
\hline \multicolumn{15}{|c|}{ Poor/non (poor food poverty line) } \\
\hline Nonpoor & 6.0 & 2.1 & 6.7 & 14.9 & 12.3 & 30.0 & 8.6 & 4.6 & 6.1 & 1.2 & 1.6 & 1.2 & 19.5 & 85.1 \\
\hline Poor & 10.2 & 5.4 & 20.5 & 36.1 & 13.5 & 5.8 & 8.2 & 3.4 & 5.7 & 10.9 & 3.3 & 0.4 & 12.7 & 63.9 \\
\hline \multicolumn{15}{|c|}{ Poor/non poor (assets poverty line) } \\
\hline
\end{tabular}




\begin{tabular}{|c|c|c|c|c|c|c|c|c|c|c|c|c|c|c|}
\hline \multicolumn{15}{|c|}{ Appendix B continued. } \\
\hline & \multicolumn{3}{|c|}{ Agriculture } & \multirow[b]{2}{*}{$\begin{array}{c}\text { Total } \\
\text { Agriculture }\end{array}$} & \multicolumn{7}{|c|}{ Nonagricultural income sources } & \multirow[b]{2}{*}{$\begin{array}{c}\text { Other } \\
\text { Public } \\
\text { Transfer }\end{array}$} & \multirow[b]{2}{*}{$\begin{array}{l}\text { Other } \\
\text { Income }\end{array}$} & \multirow[b]{2}{*}{$\begin{array}{c}\text { Total } \\
\text { Nonagricultural }\end{array}$} \\
\hline & $\begin{array}{l}\text { Agricultural } \\
\text { Enterprise }\end{array}$ & $\begin{array}{c}\text { Self - } \\
\text { Consumption }\end{array}$ & $\begin{array}{l}\text { Agricultural } \\
\text { Labor }\end{array}$ & & $\begin{array}{c}\text { Low-return } \\
\text { Nonfarm } \\
\text { Labor }\end{array}$ & $\begin{array}{l}\text { High-return } \\
\text { Nonfarm } \\
\text { Labor }\end{array}$ & $\begin{array}{l}\text { Nonfarm } \\
\text { Enterprise }\end{array}$ & $\begin{array}{l}\text { Remittances } \\
\text { Income }\end{array}$ & $\begin{array}{l}\text { Other } \\
\text { private } \\
\text { Transfer }\end{array}$ & $\begin{array}{c}\text { PROGRESA } \\
\text { Income }\end{array}$ & $\begin{array}{l}\text { PROCAMPO } \\
\text { Income }\end{array}$ & & & \\
\hline & $\begin{array}{c}\text { Income } \\
(\%)\end{array}$ & $(\%)$ & $\begin{array}{c}\text { Income } \\
(\%)\end{array}$ & $\begin{array}{c}\text { Income } \\
(\%)\end{array}$ & $\begin{array}{c}\text { Income }^{\mathrm{e}} \\
(\%)\end{array}$ & $\begin{array}{c}\text { Income } \\
(\%)\end{array}$ & $\begin{array}{c}\text { Income } \\
(\%)\end{array}$ & $(\%)$ & $\begin{array}{c}\text { Income } \\
(\%)\end{array}$ & $(\%)$ & $(\%)$ & $\begin{array}{c}\text { Income } \\
(\%)\end{array}$ & $(\%)$ & $\begin{array}{c}\text { Income } \\
(\%)\end{array}$ \\
\hline $\begin{array}{l}\text { TOTAL } \\
\text { Region }\end{array}$ & 9.5 & 3.1 & 11.3 & 23.8 & 12.3 & 23.8 & 5.7 & 5.9 & 4.4 & 3.2 & 2.8 & 0.2 & 17.8 & 76.2 \\
\hline Norte & 5.5 & 1.8 & 12.2 & 19.5 & 15.1 & 20.1 & 5.8 & 3.8 & 4.7 & 1.3 & 8.3 & 0.2 & 21.1 & 80.5 \\
\hline Capital & 2.9 & 2.2 & 5.9 & 11.0 & 35.9 & 22.4 & 5.0 & 1.5 & 4.1 & 3.1 & 1.8 & 0.1 & 15.1 & 89.0 \\
\hline Golfo & 4.7 & 1.8 & 15.7 & 22.2 & 12.5 & 21.1 & 6.6 & 1.2 & 5.3 & 5.4 & 1.2 & 0.1 & 24.5 & 77.8 \\
\hline Pacifico & 6.1 & 1.3 & 5.0 & 12.4 & 3.1 & 51.0 & 2.2 & 1.6 & 3.1 & 0.8 & 0.9 & 0.3 & 24.6 & 87.6 \\
\hline $\begin{array}{l}\text { Sur } \\
\text { Centro- }\end{array}$ & 18.3 & 6.5 & 16.4 & 41.2 & 8.0 & 8.1 & 8.5 & 10.6 & 5.0 & 5.2 & 3.0 & 0.2 & 10.2 & 58.8 \\
\hline Norte & 12.1 & 2.5 & 10.7 & 25.4 & 13.4 & 18.0 & 6.9 & 13.4 & 4.1 & 2.6 & 3.8 & 0.3 & 12.2 & 74.6 \\
\hline Centro & 9.1 & 4.8 & 13.4 & 27.3 & 22.4 & 11.9 & 5.0 & 3.8 & 5.4 & 5.0 & 1.2 & 0.4 & 17.7 & 72.7 \\
\hline
\end{tabular}




\begin{tabular}{|c|c|c|c|c|c|c|c|c|c|c|c|c|c|c|}
\hline \multicolumn{15}{|c|}{ Appendix C.1: Income shares by source and (consumption) quintile, rural Mexico (Localities with less than 2,500 inhabitants), 2002} \\
\hline & \multicolumn{3}{|c|}{ Agriculture } & \multirow[b]{2}{*}{$\begin{array}{c}1 \text { Total } \\
\text { Agriculture } \\
\text { Income } \\
(\%) \\
\end{array}$} & \multicolumn{9}{|c|}{ Nonagricultural income sources } & \multirow[b]{2}{*}{$\begin{array}{c}\text { Total } \\
\text { onagricultural } \\
\text { Income } \\
(\%) \\
\end{array}$} \\
\hline & $\begin{array}{c}\text { Agricultural } \\
\text { enterprise } \\
\text { Incomeb } \\
(\%) \\
\end{array}$ & $\begin{array}{c}\text { Self - } \\
\text { Consumption } \\
(\%)\end{array}$ & $\begin{array}{c}\text { Agricultural } \\
\text { Labor } \\
\text { Incomec } \\
(\%) \\
\end{array}$ & & $\begin{array}{c}\text { Low-return } \\
\text { Nonfarm } \\
\text { Labor income } \\
(\%) \\
\end{array}$ & $\begin{array}{c}\text { High-return } \\
\text { Nonfarm } \\
\text { Labor income } \\
(\%) \\
\end{array}$ & $\begin{array}{c}\text { Nonfarm F } \\
\text { Enterprise } \\
\text { Income } \\
(\%) \\
\end{array}$ & $\begin{array}{l}\text { Remittance } \\
\text { Income } \\
(\%)\end{array}$ & $\begin{array}{l}\text { Other private } \\
\text { Transfer } \\
\text { Income } \\
(\%) \\
\end{array}$ & $\begin{array}{l}\text { ROGRES } \\
\text { Income } \\
(\%)\end{array}$ & $\begin{array}{l}\text { ROCAMP } \\
\text { Income } \\
(\%)\end{array}$ & $\begin{array}{c}\text { Other public } \\
\text { Transfer } \\
\text { Income } \\
(\%) \\
\end{array}$ & $\begin{array}{c}\text { Other } \\
\text { Incomeel } \\
(\%)\end{array}$ & \\
\hline TOTAL & 9.5 & 3.1 & 11.3 & 23.8 & 12.3 & 23.8 & 5.7 & 5.9 & 4.4 & 3.2 & 2.8 & 0.2 & 17.8 & 76.2 \\
\hline \multicolumn{15}{|c|}{$\begin{array}{l}\text { Rural per capita } \\
\text { Consumption quintile }\end{array}$} \\
\hline Bottom & 12.4 & 6.1 & 28.1 & 46.6 & 11.5 & 2.8 & 4.3 & 1.7 & 5.1 & 12.0 & 4.7 & 0.3 & 10.9 & 53.4 \\
\hline $2^{\text {nd }}$ & 10.0 & 4.7 & 22.3 & 37.1 & 14.4 & 8.3 & 6.0 & 4.5 & 5.0 & 8.5 & 3.6 & 0.7 & 11.9 & 62.9 \\
\hline $3^{\text {rd }}$ & 10.4 & 3.6 & 20.5 & 34.6 & 16.8 & 11.1 & 7.6 & 4.7 & 4.7 & 5.7 & 2.9 & 0.4 & 11.5 & 65.4 \\
\hline $4^{\text {th }}$ & 9.9 & 2.8 & 15.3 & 28.0 & 19.0 & 14.1 & 6.7 & 8.0 & 4.7 & 3.1 & 2.5 & 0.2 & 13.5 & 72.0 \\
\hline $5^{\text {th }}$ & 8.6 & 2.4 & 3.8 & 14.8 & 8.6 & 35.4 & 5.0 & 6.2 & 4.0 & 0.6 & 2.5 & 0.1 & 22.7 & 85.2 \\
\hline \multicolumn{15}{|c|}{$\begin{array}{l}\text { Poor/non poor } \\
\text { (Food poverty line) }\end{array}$} \\
\hline Nonpoor & 9.2 & 2.6 & 9.6 & 21.4 & 12.2 & 27.0 & 5.5 & 6.2 & 4.2 & 1.7 & 2.6 & 0.2 & 18.8 & 78.6 \\
\hline Poor & 10.9 & 5.9 & 21.9 & 38.7 & 12.8 & 4.4 & 6.8 & 3.8 & 5.5 & 11.9 & 3.8 & 0.4 & 11.9 & 61.3 \\
\hline \multicolumn{15}{|c|}{$\begin{array}{l}\text { Poor/non poor } \\
\text { (Assets poverty line) }\end{array}$} \\
\hline Nonpoor & 9.5 & 2.3 & 6.2 & 17.9 & 10.1 & 32.1 & 5.2 & 6.0 & 4.0 & 0.7 & 2.5 & 0.1 & 21.5 & 82.1 \\
\hline Poor & 9.4 & 4.5 & 19.9 & 33.8 & 16.0 & 9.9 & 6.6 & 5.8 & 5.2 & 7.4 & 3.3 & 0.4 & 11.7 & 66.2 \\
\hline
\end{tabular}




\begin{tabular}{|c|c|c|c|c|c|c|c|c|}
\hline Appendix D: I & Rural Lal & Force Cha & $\begin{array}{l}\text { teristics } \\
\text { Mexico }\end{array}$ & $\begin{array}{l}\text { nd House } \\
002^{1}\end{array}$ & old Don & inant Occ & pation, & \\
\hline & & & Househol & type ${ }^{2}$ & & & & \\
\hline & $\begin{array}{c}\text { Independent } \\
\text { Farming }\end{array}$ & $\begin{array}{l}\text { Nonagricultural } \\
\text { Entrepreneurial } \\
\end{array}$ & $\begin{array}{c}\text { Agricultural } \\
\text { Wage labor }\end{array}$ & $\begin{array}{c}\text { Nonagricultural } \\
\text { Wage labor }\end{array}$ & Dependent & $\begin{array}{c}\text { Nonmonetary } \\
\text { Income }\end{array}$ & $\begin{array}{l}\text { Diversified } \\
\text { Occupation }\end{array}$ & Total \\
\hline Total Population & $1,364,514$ & $1,818,435$ & $4,092,171$ & $6,441,023$ & $3,000,006$ & $1,964,730$ & $6,371,670$ & $25,052,549$ \\
\hline$\%$ of the total pop & 5.4 & 7.3 & 16.3 & 25.7 & 12.0 & 7.8 & 25.4 & \\
\hline Dependency ratio (\%) & 33.0 & 36.1 & 34.6 & 29.8 & 43.5 & 51.4 & 34.3 & 36.5 \\
\hline Mean family size & 4.1 & 4.5 & 4.5 & 4.7 & 3.7 & 3.0 & 4.8 & 4.3 \\
\hline Individuals age $>12$ & $1,053,841$ & $1,236,674$ & $2,854,929$ & $4,582,467$ & $2,171,319$ & $1,412,859$ & $4,627,675$ & $17,939,764$ \\
\hline Labor Force & 666,482 & 753,194 & $1,566,733$ & $2,685,628$ & 844,749 & 781,001 & $2,864,058$ & $10,161,845$ \\
\hline Participation rate $(\%)$ & 63.24 & 60.90 & 54.88 & 58.61 & 38.90 & 55.28 & 61.89 & 56.64 \\
\hline Employed individuals & 663,425 & 743,086 & $1,557,815$ & $2,572,599$ & 824,950 & 770,575 & $2,839,230$ & $9,971,680$ \\
\hline $\begin{array}{l}\% \text { of the labor force } \\
\text { Labor force } \\
\text { Characteristics }\end{array}$ & 99.5 & 98.7 & 99.4 & 95.8 & 97.7 & 98.7 & 99.1 & 98.1 \\
\hline Male (\%) & 71.09 & 64.54 & 80.22 & 69.85 & 58.77 & 63.55 & 66.15 & 68.69 \\
\hline Female (\%) & 28.91 & 35.46 & 19.78 & 30.15 & 41.23 & 36.45 & 33.85 & 31.31 \\
\hline $\begin{array}{l}\text { Education Status } \\
(\%)\end{array}$ & & & & & & & & \\
\hline No education & 22.2 & 14.6 & 21.4 & 10.9 & 22.9 & 33.0 & 25.8 & 20.4 \\
\hline Primary incomplete & 36.6 & 26.0 & 38.6 & 22.1 & 36.0 & 32.5 & 30.9 & 30.3 \\
\hline Primary complete & 23.9 & 32.6 & 27.9 & 28.7 & 29.1 & 20.4 & 26.8 & 27.4 \\
\hline Secondary complete & 12.7 & 20.3 & 11.8 & 21.8 & 11.1 & 11.9 & 13.2 & 15.5 \\
\hline Higher education & 4.7 & 6.5 & 0.3 & 16.5 & 0.9 & 2.2 & 3.3 & 6.4 \\
\hline $\begin{array}{l}\text { Mean age } \\
\text { Age Cohort (\%) }\end{array}$ & 42.6 & 38.0 & 37.2 & 34.3 & 42.4 & 45.6 & 38.5 & \\
\hline$<15$ & 2.2 & 5.4 & 2.7 & 1.9 & 6.6 & 3.4 & 4.4 & 3.5 \\
\hline 15 to 25 & 18.9 & 20.0 & 29.6 & 32.1 & 22.4 & 15.9 & 26.0 & 26.2 \\
\hline 26 to 40 & 27.6 & 36.4 & 30.4 & 36.2 & 15.8 & 28.1 & 26.4 & 29.7 \\
\hline 41 to 60 & 32.2 & 24.7 & 26.5 & 24.4 & 35.0 & 23.8 & 30.6 & 27.8 \\
\hline$>61$ & 19.0 & 13.6 & 10.8 & 5.4 & 20.2 & 28.8 & 12.6 & 12.8 \\
\hline Not in Labor force & 387,359 & 483,480 & $1,288,196$ & $1,896,839$ & $1,326,570$ & 631,858 & $1,763,617$ & $7,777,919$ \\
\hline$(\%)$ of the Pop $>12$ & 36.8 & 39.1 & 45.1 & 41.4 & 61.1 & 44.7 & 38.1 & 43.4 \\
\hline
\end{tabular}




\begin{tabular}{|c|c|c|c|c|c|c|c|c|}
\hline \multicolumn{9}{|c|}{ Appendix D continued } \\
\hline \multicolumn{9}{|c|}{ Not in Labor force Characteristics } \\
\hline Male (\%) & 21.32 & 19.09 & 14.66 & 23.16 & 28.71 & 21.18 & 24.38 & 22.47 \\
\hline Female (\%) & 78.68 & 80.91 & 85.34 & 76.84 & 71.29 & 78.82 & 75.62 & 77.53 \\
\hline \multicolumn{9}{|l|}{$\begin{array}{l}\text { Education Status } \\
(\%)\end{array}$} \\
\hline No education & 20.6 & 15.0 & 21.4 & 13.1 & 20.6 & 28.8 & 18.0 & 18.6 \\
\hline Primary incomplete & 26.3 & 16.4 & 29.6 & 22.2 & 28.2 & 34.3 & 28.3 & 26.6 \\
\hline Primary complete & 36.8 & 34.4 & 34.9 & 37.8 & 36.4 & 25.8 & 38.1 & 35.9 \\
\hline Secondary complete & 14.4 & 26.6 & 13.4 & 20.5 & 13.6 & 9.8 & 14.7 & 16.0 \\
\hline Higher education & 1.9 & 7.6 & 0.8 & 6.5 & 1.2 & 1.4 & 0.9 & 2.8 \\
\hline Mean age & 36.4 & 30.6 & 29.7 & 29.6 & 37.2 & 44.1 & 30.1 & \\
\hline \multicolumn{9}{|l|}{ Age cohort (\%) } \\
\hline$<15$ & 21.4 & 21.4 & 23.1 & 21.1 & 21.7 & 16.3 & 28.4 & 22.8 \\
\hline 15 to 25 & 21.7 & 27.1 & 30.1 & 33.9 & 23.4 & 18.5 & 29.0 & 28.1 \\
\hline 26 to 40 & 17.0 & 27.4 & 21.5 & 21.0 & 14.8 & 16.9 & 15.2 & 18.6 \\
\hline 41 to 60 & 21.2 & 14.6 & 17.9 & 14.6 & 18.2 & 14.5 & 15.9 & 16.4 \\
\hline$>61$ & 18.8 & 9.5 & 7.4 & 9.4 & 21.9 & 33.8 & 11.6 & 14.2 \\
\hline \multicolumn{9}{|c|}{$\begin{array}{l}\text { Source: ENIGH } 2002 .{ }^{1} \text { Rural area defined as localities with less than } 2,500 \text { inhabitants. }{ }^{2} \text { The households are classified according to their per } \\
\text { capita current income as follows: Independent farming: Households with more than } 50 \% \text { of their current income coming from independent } \\
\text { agropecuarian production; Nonagricultural entrepreneurial: Households with more than } 50 \% \text { of their current income coming from } \\
\text { independent non agricultural activities; Agricultural wage labor : Households with more than } 50 \% \text { of their current income coming from } \\
\text { agricultural wage labor; Nonagricultural wage labor : Households with more than } 50 \% \text { of their current income coming from non } \\
\text { agricultural wage labor; Nonmonetary income : Households with more than } 50 \% \text { of their current income coming from nonmonetary income; } \\
\text { Diversified occupation : Households with less than } 50 \% \text { of their current coming from any of the above. }\end{array}$} \\
\hline
\end{tabular}




\begin{tabular}{|c|c|c|c|c|c|c|c|c|}
\hline \multicolumn{9}{|c|}{$\begin{array}{c}\text { Appendix D continued: Rural Labor Force Characteristics and Household Dominant Occupation, } \\
\text { Mexico } 2002^{1}\end{array}$} \\
\hline \multicolumn{9}{|c|}{ Household type $^{2}$} \\
\hline & $\begin{array}{l}\text { Independent } \\
\text { Farming }\end{array}$ & $\begin{array}{l}\text { Nonagricultural } \\
\text { Entrepreneurial }\end{array}$ & $\begin{array}{c}\text { Agricultural } \\
\text { Wage labor }\end{array}$ & $\begin{array}{c}\text { Nonagricultural } \\
\text { Wage labor }\end{array}$ & Dependent & $\begin{array}{c}\text { Nonmonetary } \\
\text { Income }\end{array}$ & $\begin{array}{l}\text { Diversified } \\
\text { Occupation }\end{array}$ & Total \\
\hline Total Population & $1,364,514$ & $1,818,435$ & $4,092,171$ & $6,441,023$ & $3,000,006$ & $1,964,730$ & $6,371,670$ & $25,052,549$ \\
\hline$\%$ of the total pop & 5.4 & 7.3 & 16.3 & 25.7 & 12.0 & 7.8 & 25.4 & \\
\hline Dependency ratio $(\%)$ & 33.0 & 36.1 & 34.6 & 29.8 & 43.5 & 51.4 & 34.3 & 36.5 \\
\hline Mean family size & 4.1 & 4.5 & 4.5 & 4.7 & 3.7 & 3.0 & 4.8 & 4.3 \\
\hline Individuals age $>12$ & $1,053,841$ & $1,236,674$ & $2,854,929$ & $4,582,467$ & $2,171,319$ & $1,412,859$ & $4,627,675$ & $17,939,764$ \\
\hline Labor Force & 666,482 & 753,194 & $1,566,733$ & $2,685,628$ & 844,749 & 781,001 & $2,864,058$ & $10,161,845$ \\
\hline Participation rate $(\%)$ & 63.24 & 60.90 & 54.88 & 58.61 & 38.90 & 55.28 & 61.89 & 56.64 \\
\hline Employed individuals & 663,425 & 743,086 & $1,557,815$ & $2,572,599$ & 824,950 & 770,575 & $2,839,230$ & $9,971,680$ \\
\hline$\%$ of the labor force & 99.5 & 98.7 & 99.4 & 95.8 & 97.7 & 98.7 & 99.1 & 98.1 \\
\hline \multicolumn{9}{|l|}{$\begin{array}{l}\text { Labor force } \\
\text { Characteristics }\end{array}$} \\
\hline Male (\%) & 71.09 & 64.54 & 80.22 & 69.85 & 58.77 & 63.55 & 66.15 & 68.69 \\
\hline Female (\%) & 28.91 & 35.46 & 19.78 & 30.15 & 41.23 & 36.45 & 33.85 & 31.31 \\
\hline \multicolumn{9}{|l|}{$\begin{array}{l}\text { Education Status } \\
(\%)\end{array}$} \\
\hline No education & 22.2 & 14.6 & 21.4 & 10.9 & 22.9 & 33.0 & 25.8 & 20.4 \\
\hline Primary incomplete & 36.6 & 26.0 & 38.6 & 22.1 & 36.0 & 32.5 & 30.9 & 30.3 \\
\hline Primary complete & 23.9 & 32.6 & 27.9 & 28.7 & 29.1 & 20.4 & 26.8 & 27.4 \\
\hline Secondary complete & 12.7 & 20.3 & 11.8 & 21.8 & 11.1 & 11.9 & 13.2 & 15.5 \\
\hline Higher education & 4.7 & 6.5 & 0.3 & 16.5 & 0.9 & 2.2 & 3.3 & 6.4 \\
\hline Mean age & 42.6 & 38.0 & 37.2 & 34.3 & 42.4 & 45.6 & 38.5 & \\
\hline \multicolumn{9}{|l|}{ Age Cohort (\%) } \\
\hline$<15$ & 2.2 & 5.4 & 2.7 & 1.9 & 6.6 & 3.4 & 4.4 & 3.5 \\
\hline 15 to 25 & 18.9 & 20.0 & 29.6 & 32.1 & 22.4 & 15.9 & 26.0 & 26.2 \\
\hline 26 to 40 & 27.6 & 36.4 & 30.4 & 36.2 & 15.8 & 28.1 & 26.4 & 29.7 \\
\hline 41 to 60 & 32.2 & 24.7 & 26.5 & 24.4 & 35.0 & 23.8 & 30.6 & 27.8 \\
\hline$>61$ & 19.0 & 13.6 & 10.8 & 5.4 & 20.2 & 28.8 & 12.6 & 12.8 \\
\hline Not in Labor force & 387,359 & 483,480 & $1,288,196$ & $1,896,839$ & $1,326,570$ & 631,858 & $1,763,617$ & $7,777,919$ \\
\hline$(\%)$ of the Pop $>12$ & 36.8 & 39.1 & 45.1 & 41.4 & 61.1 & 44.7 & 38.1 & 43.4 \\
\hline \multicolumn{9}{|c|}{ Not in Labor force Characteristics } \\
\hline Male (\%) & 21.32 & 19.09 & 14.66 & 23.16 & 28.71 & 21.18 & 24.38 & 22.47 \\
\hline
\end{tabular}




\begin{tabular}{|c|c|c|c|c|c|c|c|c|}
\hline \multicolumn{9}{|c|}{ Appendix D continued } \\
\hline Female (\%) & 78.68 & 80.91 & 85.34 & 76.84 & 71.29 & 78.82 & 75.62 & 77.53 \\
\hline \multicolumn{9}{|l|}{$\begin{array}{l}\text { Education Status } \\
(\%)\end{array}$} \\
\hline No education & 20.6 & 15.0 & 21.4 & 13.1 & 20.6 & 28.8 & 18.0 & 18.6 \\
\hline Primary incomplete & 26.3 & 16.4 & 29.6 & 22.2 & 28.2 & 34.3 & 28.3 & 26.6 \\
\hline Primary complete & 36.8 & 34.4 & 34.9 & 37.8 & 36.4 & 25.8 & 38.1 & 35.9 \\
\hline Secondary complete & 14.4 & 26.6 & 13.4 & 20.5 & 13.6 & 9.8 & 14.7 & 16.0 \\
\hline Higher education & 1.9 & 7.6 & 0.8 & 6.5 & 1.2 & 1.4 & 0.9 & 2.8 \\
\hline Mean age & 36.4 & 30.6 & 29.7 & 29.6 & 37.2 & 44.1 & 30.1 & \\
\hline \multicolumn{9}{|l|}{ Age cohort (\%) } \\
\hline$<15$ & 21.4 & 21.4 & 23.1 & 21.1 & 21.7 & 16.3 & 28.4 & 22.8 \\
\hline 15 to 25 & 21.7 & 27.1 & 30.1 & 33.9 & 23.4 & 18.5 & 29.0 & 28.1 \\
\hline 26 to 40 & 17.0 & 27.4 & 21.5 & 21.0 & 14.8 & 16.9 & 15.2 & 18.6 \\
\hline 41 to 60 & 21.2 & 14.6 & 17.9 & 14.6 & 18.2 & 14.5 & 15.9 & 16.4 \\
\hline$>61$ & 18.8 & 9.5 & 7.4 & 9.4 & 21.9 & 33.8 & 11.6 & 14.2 \\
\hline \multicolumn{9}{|c|}{$\begin{array}{l}\text { Source: ENIGH } 2002 .{ }^{1} \text { Rural area defined as localities with less than } 2,500 \text { inhabitants. }{ }^{2} \text { The households are classified according to their per } \\
\text { capita current income as follows: Independent farming: Households with more than } 50 \% \text { of their current income coming from independent } \\
\text { agropecuarian production; Nonagricultural entrepreneurial: Households with more than } 50 \% \text { of their current income coming from } \\
\text { independent non agricultural activities; Agricultural wage labor : Households with more than } 50 \% \text { of their current income coming from } \\
\text { agricultural wage labor; Nonagricultural wage labor : Households with more than } 50 \% \text { of their current income coming from non } \\
\text { agricultural wage labor; Nonmonetary income : Households with more than } 50 \% \text { of their current income coming from nonmonetary income; } \\
\text { Diversified occupation : Households with less than } 50 \% \text { of their current coming from any of the above. }\end{array}$} \\
\hline
\end{tabular}

